Canadian

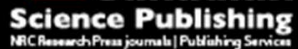

Canadian Journal of Earth Sciences Revue canadienne des sciences de la Terre

\title{
Age and tectonic setting of granitoid plutons in the Chéticamp belt, western Cape Breton Island, Nova Scotia, Canada
}

\begin{tabular}{|r|l|}
\hline Journal: & Canadian Journal of Earth Sciences \\
\hline Manuscript ID & cjes-2016-0073.R1 \\
\hline Danuscript Type: & Article \\
\hline Complete List of Authors: & $\begin{array}{l}\text { Slaman, Lisa; Acadia University, Earth and Environmental Science } \\
\text { Barr, Sandra; Department of Earth and Environmental Science, } \\
\text { White, Chris; Nova Scotia Department of Natural Resources } \\
\text { van Rooyen, Deanne; Cape Breton University, Mathematics, Physics and } \\
\text { Geology }\end{array}$ \\
\hline Keyword: & $\begin{array}{l}\text { Ganderia, U-Pb (zircon) dating, whole-rock geochemistry, Sm-Nd isotopes, } \\
\text { Appalachian orogen }\end{array}$ \\
\hline \multicolumn{2}{|c}{} \\
\hline
\end{tabular}

SCHOLARONE

Manuscripts 


\section{Age and tectonic setting of granitoid plutons in the Chéticamp belt, western Cape Breton Island, Nova Scotia, Canada}

L.R. Slaman, S.M. Barr, C.E. White, and D. Van Rooyen

L. R. Slaman, Department of Earth and Environmental Science, Acadia University, Wolfville, Nova Scotia B4P 2R6, Canada lisa.r.slaman@gmail.com

S. M. Barr, Department of Earth and Environmental Science, Acadia University, Wolfville, Nova Scotia B4P 2R6, Canada sandra.barr@acadiau.ca

C.E. White, Nova Scotia Department of Natural Resources, Box 698, Halifax, Nova Scotia B3J 2T9, Canada Christopher.E.White@,novascotia.ca

D. Van Rooyen, Geology, School of Science \& Technology, Cape Breton University, Sydney, Nova Scotia, B1P 6L2, Canada deanne vanrooyen@,cbu.ca

Corresponding author:

Sandra M. Barr,

Department of Earth and Environmental Science, Acadia University, Wolfville, Nova Scotia B4P 2R6, Canada

Telephone: 902-585-1340

FAX: 902-585-1816

sandra.barr@,acadiau.ca 
Age and tectonic setting of granitoid plutons in the Chéticamp belt, western Cape Breton Island, Nova Scotia, Canada

L.R. Slaman, S.M. Barr, C.E. White, and D. Van Rooyen

\begin{abstract}
Geological mapping in the Chéticamp granitoid belt in combination with petrographic and geochemical studies and $\mathrm{U}-\mathrm{Pb}$ (zircon) dating by laser ablation inductively coupled plasma mass spectrometry have resulted in major reinterpretation of the geology in the western part of the Ganderian Aspy terrane of Cape Breton Island. Nine new U-Pb (zircon) ages show that the former “Chéticamp pluton” consists of 10 separate plutons of 5 different ages: Late Neoproterozoic (ca. $567 \mathrm{Ma}$ ), Cambrian-Ordovician (490-482 Ma), Ordovician-Silurian (442-440 Ma), mid-Silurian (ca. $428 \mathrm{Ma}$ ), and late Devonian (366 Ma). The three Late Neoproterozoic granodioritic to monzogranitic plutons are older than the adjacent metavolcanic and metasedimentary rocks of the Jumping Brook Metamorphic Suite, whereas the tonalitic to quartz dioritic Cambrian-Ordovician plutons intruded those metamorphic rocks. Petrographic characteristics and approximately 100 whole-rock chemical analyses show that with the exception of the mid-Silurian Grand Falaise alkali-feldspar granite which has A-type within-plate characteristics, the plutonic units have calcalkaline affinity and were emplaced in a volcanic-arc tectonic setting. These results are evidence that fragments of a long history of episodic subduction-related magmatism and terrane collision is preserved in this small part of Ganderia. Eight new Sm-Nd isotopic analyses are consistent with the Ganderian affinity of the Chéticamp plutonic belt. The ca. 490-482 Ma plutons are the first direct evidence in Cape Breton Island for the Penobscottian event recognized in the Exploits subzone of central Newfoundland and in New Brunswick. However, the structural relationship of the
\end{abstract}


Chéticamp plutonic belt to the rest of the Aspy and Bras d'Or terranes remains enigmatic, as is the apparent absence of effects of Devonian deformation and metamorphism in the older plutonic units.

Key words: Ganderia, U-Pb (zircon) dating, whole-rock geochemistry, Sm-Nd isotopes, Appalachian orogen

\section{Introduction}

Ganderia, the central domain of the northern Appalachian orogen (Fig. 1 inset), is a complex area of Neoproterozoic to Devonian rocks interpreted to be of peri-Gondwanan affinity. It is sandwiched between the Neoproterozoic-Paleozoic Laurentian margin and related peri-Laurentian terranes on the northwest and Neoproterozoic to Devonian rocks of Avalonia on the southeast. The defining characteristics of Ganderia and tectonic models for its interaction with Laurentia and Avalonia have been developed based mainly on studies in central Newfoundland and New Brunswick, Canada. Those models suggest that arrival of the leading edge of Ganderia at the active Laurentian margin led to Late Ordovician closure of the main tract of the Iapetus Ocean, and its trailing edge (Gander margin) accreted during the Early Silurian Salinic orogeny following closure of a wide back-arc basin that had split Ganderia into two halves while crossing Iapetus (e.g., van Staal 1994; van Staal et al. 2003, 2008, 2009, 2011; Hibbard et al. 2007; Nance et al. 2008; Zagorevski et al. 2010; van Staal and Barr 2012).

In Cape Breton Island (Fig. 1), Ganderian rocks occur in two fault-bounded terranes termed Bras d'Or and Aspy (Barr and Raeside 1989; Barr et al. 1996, 1998). Boundaries between these Ganderian terranes and adjacent Laurentian (as represented by the Blair River Inlier) and Avalonian (Mira terrane) elements are obscured by Carboniferous sedimentary cover and faults, but are considered to be cryptic sutures that resulted from promontory-promontory collision (Lin et al. 1994; Barr et al. 1995, 1998). As a result, in comparison to both Newfoundland and New 
Brunswick, central Cape Breton Island preserves only a condensed Ganderian section, from which many of the defining elements of Ganderia such as ophiolitic rocks, Cambrian-Ordovician Gander margin sedimentary sequences, and Cambrian-Ordovician volcanic arcs appear to be missing. In addition, complex field relationships and limited age constraints have made correlation of specific rock units with Ganderian components elsewhere challenging (Lin et al. 2007; Barr et al. 2014).

A belt of granitoid plutons forms most of the westernmost Cape Breton Highlands in the Chéticamp area of the Aspy terrane (Fig. 1). Most mapping and petrological studies in the Chéticamp plutonic belt were done decades ago (e.g. Barr et al. 1986, 1992; Currie 1987; Jamieson et al. 1986, 1987; 1989), and neither age nor tectonic setting was well constrained during those studies. Barr and Raeside (1989) included the area in their Aspy terrane, but recognized that the Late Neoproterozoic plutonic rocks in the area are not typical of that terrane, which is elsewhere dominated by Silurian and Devonian plutons. Hence they suggested instead a possible link with the Bras d'Or terrane of central Cape Breton Island (Fig. 1), although the tectonic implications of that interpretation are clearly problematic.

The purpose of this paper is to present the results of new mapping, petrological studies, and $\mathrm{U}-\mathrm{Pb}$ (zircon) dating which focuses on the plutonic rocks of the Chéticamp belt. Most of these plutonic rocks were included previously in the "Chéticamp pluton" and assigned a probable Late Neoproterozoic age (Currie 1987; Jamieson et al. 1986; Barr et al. 1986, 1992). The new data show that plutonic rocks in the belt were emplaced episodically between the Late Neoproterozoic and mid-Devonian, and provide improved constraints on their chemical affinity, source rocks, and tectonic setting. These results provide an enhanced basis for comparison and correlation with rock units in other parts of Cape Breton Island and elsewhere in the northern Appalachian orogen, in particular central Newfoundland, and show the presence of previously unrecognized Late Cambrian-Early Ordovician Ganderian elements in the Aspy terrane. 


\section{Geological Setting}

The Aspy terrane is dominated by varied Silurian-Devonian plutonic rocks with arc, collisional, and within-plate characteristics (Barr and Raeside 1989; Barr 1990; Yaowanoiyothin and Barr 1991). The plutons intruded metamorphic rocks of low- to high-grade, and mainly of uncertain protolith age, although some dated Early Silurian volcanic rocks have potential correlatives in southern Newfoundland and New Brunswick (Barr and Jamison 1991; Barr et al. 2014). The Cambrian to Lower Ordovician quartz-rich slope and rise deposits typical of other parts of Ganderia, such as the Miramichi Group in New Brunswick and the Gander Group in Newfoundland (e.g., Hibbard et al. 2006), do not appear to be represented in the Aspy terrane, where metamorphic components are of inferred Ordovician-Silurian age, although age constraints are limited (Barr and Jamieson 1991; Lin et al. 2007).

In contrast to the Aspy terrane, the Bras d'Or terrane is characterized by platformal quartzite-carbonate-pelite sequences of mid- to late Neoproterozoic age intruded by abundant Late Neoproterozoic-Early Cambrian continental magmatic arc plutons (Fig. 1). Bras d'Or is considered to be representative of Ganderian "basement” on which the Cambrian-Ordovician Gander margin was built (Pollock 2007; Hibbard et al. 2006; Barr et al. 2013; White et al. 2016a). Scattered midto late Cambrian igneous activity has been linked to extension related to the separation of Ganderia from Gondwana (White et al. 1994; van Staal and Barr 2012).

In contrast to most plutons in the Aspy terrane, the Chéticamp pluton of the westernmost highlands has long been considered to be Neoproterozoic, based on the $\mathrm{U}-\mathrm{Pb}$ (zircon) age of $550 \pm$ 8 Ma reported by Jamieson et al. (1986) from a muscovite-biotite monzogranite sample. Based on their petrological studies, Barr et al. (1986) considered the dated unit to be co-genetic with the more extensive biotite ( \pm hornblende) granodiorite which formed the northern part of the pluton, although 
the two units are in faulted contact. Barr et al. (1986) also reported a Rb-Sr isochron date of $525 \pm$ 40 Ma using samples from both rock types, but the U-Pb age of Jamieson et al. (1986) was accepted as more accurate. Significantly, the study of Barr et al. (1986) did not include plutonic units in the northern and southern parts of the Chéticamp plutonic belt. Based on mapping by Currie (1987) and Jamieson et al. (1989), Barr et al. (1992) extended the Chéticamp pluton north of the area studied by Barr et al. (1986), as well as recognizing a separate unnamed granitic unit of uncertain (Precambrian to Devonian) age even farther to the north. On its southern margin, the muscovitebiotite monzogranite unit of the Chéticamp pluton was interpreted to have intruded unnamed gneissic and dioritic rocks, based on local evidence of cross-cutting relations (Barr et al. 1986). A separate undated granitic pluton in that area was named MacLean Brook and a Devonian age was suggested based on the relatively unaltered appearance of the rock compared to the Chéticamp pluton. All of these rocks are unconformably overlain by or in faulted contact with Devonian volcanic and sedimentary rocks of the Fisset Brook Formation and locally by younger Carboniferous sedimentary rocks (Barr et al. 1992), and all are terminated abruptly on the southeast at a major fault (Fig. 2).

On the northern and northeastern margins, the Chéticamp pluton of Barr et al. (1992) is in contact with the Jumping Brook Metamorphic Suite (JBMS). The JBMS includes varied metasedimentary rocks, mafic and felsic metavolcanic rocks, and amphibolite of uncertain age and it is not clear whether these rocks are intruded by the plutonic rocks of the area or whether all of the contacts are faults or unconformities (e.g., Jamieson et al. 1989, 1990; Lin et al. 2007; Tucker 2011). Lin et al. (2007) presented U-Pb (zircon) ages from the Jumping Brook Metamorphic Suite which suggest that it has a maximum depositional age of ca. 550-540 Ma, indicating that contacts with the pluton are faulted, if the Neoproterozoic age of Jamieson et al. (1986) for the Chéticamp pluton is correct. 
Because plutonic rocks of Late Neoproterozoic age are a major component of the Bras d'Or terrane, Raeside and Barr (1990) postulated that the Chéticamp pluton may represent a klippe of the Bras d'Or terrane, although detailed structural studies to support or disprove this interpretation have not been done. In support of the klippe model, magmatic muscovite in the southern part of the pluton is Late Neoproterozoic and lacks evidence for the pervasive Devonian overprint recorded elsewhere in the Aspy terrane (Reynolds et al. 1989; Price et al. 1999). Lin (1992, 1993) proposed that the Chéticamp area may be a remnant of Bras d'Or terrane which was separated from the rest of the terrane by the formation of a back-arc basin, a model also adopted by Barr et al. (1998). Alternatively, it has also been suggested that the Chéticamp pluton and associated rocks may continue as part of the Bras d'Or terrane at depth, underneath younger Silurian-Devonian rocks of an overthrust nappe (Lynch and Tremblay 1992, 1994; Dallmeyer and Keppie 1993).

\section{Field Relations and Petrography}

As a result of additional mapping and sampling, as well as re-examination of the sample suite studied by Barr et al. (1986), plutonic rocks in the Chéticamp belt have been divided into 10 units (Fig. 2). The petrographic similarities and differences among these units are supported by geochronological and chemical data, as described here.

The Farm Brook granodiorite corresponds mainly to the biotite granodiorite and megacrystic biotite granodiorite units of Barr et al. (1986). It is in faulted contact on it eastern margin with Devonian volcanic and sedimentary rocks of the Fisset Brook Formation, whereas its western contact with the same formation is mainly a nonconformity, now dipping steeply to the west, as also noted by Barr et al. (1986) and Barr and Peterson (1998). The modal compositions of samples from the unit are mainly granodiorite, but grade to monzogranite. Texture ranges from hypidiomorphic equigranular to inequigranular and locally megacrystic with large crystals of microcline. Major 
minerals are microcline (20-30\%), quartz (20-30\%), plagioclase (40-50\%), and biotite (5-15\%).

Microcline formed later than and tends to enclose plagioclase and biotite, especially in megacrystic samples. Biotite in many samples contains relict cores of euhedral to subhedral zoned epidote with characteristics consistent with magmatic origin (Zen and Hammarstrom 1984, 1988). Other accessory minerals include apatite, titanite, zircon, and magnetite.

The Rigwash Brook granodiorite is in mainly faulted contact with adjacent units. Along its southwestern margin, it has been thrust over the Devonian Fisset Brook Formation, whereas along its northern margin, it has been overthrust by the Jumping Brook Metamorphic Suite (Fig. 2). Its eastern margin is mainly a fault against the Chéticamp River tonalite. It is intruded by small bodies of Grand Falaise alkali-feldspar granite and small granitic bodies interpreted to be related to the Devonian Salmon Pool pluton (Fig. 2). The Rigwash Brook granodiorite is petrographically similar to the Farm Brook granodiorite, and consists of plagioclase, microcline, quartz, and biotite with accessory epidote, apatite, zircon, titanite, and opaque minerals. Large poikilitic grains of microcline and euhderal epidote in the cores of biotite grains are distinctive features in both units.

The Pembroke Lake monzogranite is located south of and in probable faulted contact with the Farm Brook granodiorite (Fig. 2). Like the granodiorite, the monzogranite body is nonconformably overlain by the Fisset Brook Formation on the western margin of the pluton but elsewhere the contact is generally faulted. On its southern margin, the monzogranite is associated with metamorphic rocks of the Stewart Brook Formation. Relationships are unclear, but map patterns suggest that the Stewart Brook Formation was intruded by the monzogranite, and both units are intruded by the Lavis Brook quartz diorite and MacLean Brook granodiorite (Fig. 2). The Pembroke Lake pluton is mainly monzogranite but locally grades to granodiorite. Major minerals are plagioclase (30-40\%), quartz (20-30\%), microcline (20-30\%), biotite (5-10\%), and muscovite $(5-10 \%)$. Muscovite is absent and biotite content is higher in some granodioritic samples. Texture 
ranges from mainly equigranular to locally megacrystic with large crystals of microcline that tend to include earlier formed, smaller, subhedral plagioclase crystals. This distinctive texture is similar to that in the Farm Brook and Rigwash granodiorite units. Another similarity to the granodiorite units is the common presence of relict cores of euhedral to subhedral zoned epidote with some characteristics of magmatic origin (Zen and Hammarstrom 1984, 1988). Other accessory minerals include apatite, zircon, and opaque minerals.

The Canadian Brook tonalite is located in the northern part of the Chéticamp plutonic belt and was part of the unit designated as "undifferentiated granitoid rocks" of uncertain age by Barr et al. (1992). The contact of the tonalite with adjacent metamorphic rocks of the Jumping Brook Metamorphic Suite is faulted on the west but appears to be intrusive on the east. Along the Cabot Trail in the French Mountain area sheets of tonalite occur in metasedimentary rocks of the Jumping Brook suite. The modal composition grades from tonalite to granodiorite; the most abundant mineral is plagioclase (40-60\%), followed by quartz (20\%), biotite (15-20\%), amphibole (5-10\%), and in some samples perthitic orthoclase (less than 5\%). Apatite, zircon, and opaque minerals are the accessory components. Texture is fine- to medium-grained allotriomorphic inequigranular and locally foliated. In many samples both biotite and amphibole have been replaced by chlorite and the rocks have a recrystallized appearance with abundant small euhedral epidote crystals of apparent contact metamorphic origin scattered randomly through the rock.

The Chéticamp River tonalite occurs in the area between the Farm Brook and Rigwash Brook granodiorite bodies, with which it has faulted contacts (Fig. 2). Its contacts with the Jumping Brook Metamorphic Suite are interpreted to be intrusive based on the presence of metasedimentary and amphibolitic xenoliths along its northeastern margin. This unit was included in the Chéticamp pluton of earlier workers (Currie 1987; Barr et al. 1992) but its inaccessibility meant that few outcrops had been examined or sampled. Barr et al. (1986) had only a few samples from the 
southern part of the pluton, and in outcrop and hand sample it appears similar to the Farm Brook and Rigwash Brook granodiorite units. Its petrographic characteristics are similar to those of the Canadian Brook tonalite as described above.

The Upper Fisset Brook quartz diorite occurs in a small area east of the Farm Brook granodiorite. It is nonconformably overlain by the Fisset Brook Formation on its western edge, which separates it from the faulted eastern margin of the Farm Brook granodiorite (Fig. 2). The contact with the surrounding Jumping Brook Metamorphic Suite is inferred to be intrusive, based on the presence of mafic xenoliths possibly derived from volcanic units in the suite. The Upper Fisset Brook unit varies in composition from diorite to quartz diorite and tonalite, with increasing abundance of quartz and less abundant amphibole and biotite. Subhedral plagioclase laths comprise approximately $60 \%$ of most samples, with quartz up to $10-15 \%$. Amphibole forms up to 20-30\%, and biotite about $10 \%$, with accessory opaque minerals, apatite, titanite, and zircon. Overall, the texture is fine- to medium-grained, hypidiomorphic equigranular to inequigranular. More tonalitic samples are similar in texture and mineralogy to the Chéticamp River and Canadian Brook tonalite units.

The Lavis Brook quartz diorite occurs in the southernmost part of the Chéticamp plutonic belt, where it is in places nonconformably overlain by volcanic and sedimentary rocks of the Fisset Brook Formation, and elsewhere in faulted contact with that formation. Its distribution pattern suggests that it intruded metasedimentary rocks of the Stewart Brook Formation, a relationship supported by the presence of biotite and cordierite porphyroblasts in rocks of the Stewart Brook Formation near contacts with the quartz diorite. The Lavis Brook unit is varied in composition and texture. Quartz diorite is most abundant but grades to tonalite, quartz monzodiorite, and granodiorite. Texture varies from medium- to coarse-grained, and from hypidiomorphic equigranular to somewhat porphyritic with larger crystals of plagioclase and minor K-feldspar in a 
finer grained groundmass. Plagioclase is the most abundant mineral, ranging from $50 \%$ to $70 \%$. Quartz is present in amounts of $10 \%$ to $20 \%$. Amphibole is the most abundant ferromagnesian mineral, forming $20 \%$ to $30 \%$ on average, but biotite is also present in amounts up to $10 \%$ in some samples. Titanite and opaque minerals are the most abundant accessory phases; apatite and zircon occur as inclusions in amphibole and biotite. Local evidence for magma mingling with granodiorite of the MacLean Brook granodiorite indicates that the two units are co-magmatic.

The MacLean Brook granodiorite is the southernmost plutonic unit in the study area, and is cut off by the Northeast Margaree River Fault (Fig. 2). In addition to the main body, it also occurs in a small area along the fault to the northeast, where it appears to have intruded the Pembroke Lake monzogranite and is nonconformably overlain by the Fisset Brook Formation. Plagioclase is the most abundant mineral, forming $40-50 \%$ as subhedral to euhedral laths. Quartz is also abundant, making up 25-30\%. Orthoclase is less abundant and interstitial, surrounded by larger quartz grains and plagioclase laths. The dominant ferromagnesian mineral is amphibole, which makes up $15-20 \%$ of the rocks; smaller, subhedral grains of reddish-brown biotite form the remaining 5 to $10 \%$, with minor opaque minerals. Accessory apatite and zircon occur mainly as inclusions in amphibole and biotite. This pluton is locally cut by thin $(<20 \mathrm{~cm}$ wide) plagioclase porphyritic mafic dykes that are typically sinuous and display cuspate margins with the host granodiorite.

The Grand Falaise alkali-feldspar granite forms the cliff at Grand Falaise, where it has been thrust over volcanic and sedimentary rocks of the Fisset Brook Formation. At the top of the cliff section rocks of the Fisset Brook Formation nonconformably overlie the granite. Similar rocks occur in an area to the east within the Rigwash Brook granodiorite, and as dykes in the granodiorite. Hence it is likely that the Grand Falaise alkali-feldspar granite intruded the Rigwash Brook granodiorite and that both units are thrust over the Fisset Brook Formation (Fig. 2). Most samples of the Grand Falaise unit consist almost entirely of K-feldspar and quartz in coarse to fine 
granophyric intergrowths. However, some samples lack granophyre and have medium- to coarsegrained allotriomorphic granular texture.

The French Mountain syenogranite occurs in the area of French Mountain along the Cabot Trail where it intruded the western margin of the Canadian Brook tonalite (Fig. 2). It is overlain nonconformably on the west by steeply dipping sandstone and conglomerate of the Horton Group, which contains angular clasts of the syenogranite. The syenogranite contains perthitic microcline $(50 \%)$, quartz (30\%), plagioclase $(15 \%)$, and small amounts of chloritized biotite $(<5 \%)$. Texture varies from allotriomorphic equigranular to porphyritic. Interstitial microgranophyre in one sample is indicative of shallow emplacement.

\section{U-Pb Dating}

Methods

Nine samples were selected for U-Pb (zircon) dating, one from each of the Rigwash Brook granodiorite, Pembroke Lake monzogranite, Canadian Brook tonalite, Chéticamp River tonalite, Upper Fisset Brook quartz diorite, Lavis Brook quartz diorite, MacLean Brook granodiorite, Grand Falaise alkali-feldspar granite, and French Mountain syenogranite from locations indicated on Figure 2. Samples were sent to Overburden Drilling Management (ODM) in Ottawa, Ontario, for electro-pulse disaggregation and zircon separation. Zircon grains were then picked (at Cape Breton University), mounted in an epoxy- covered thin section (this and all subsequent steps at the University of New Brunswick Fredericton), polished to expose the centres of the zircon grains and imaged using cold cathodoluminescence to identify internal zoning and inclusions. These images were used to select ablation points (30 $\mu \mathrm{m}$ diameter), avoiding any visible inclusions, cracks, or other imperfections. In some cases we did multiple analyses in a single grain and two ablation points were chosen: one near the margin of the grain and one near the centre of the grain. The 
cathodoluminescence images as well as additional backscattered electron images (Fig. 3) were collected with a JEOL JSM-6400 operating at $15 \mathrm{kV}$ with a probe current of $1.5 \mathrm{nA}$, and equipped with Digital Micrograph (Gatan, Inc.), using a Gatan ChromaCL system and dwell times $500 \mu \mathrm{s}$ specifically for the cathodoluminescence images. The images in Figure 3 show the typical oscillatory zoning observed in most of the analyzed zircon grains, as well as their typical euhedral shapes.

$\mathrm{U}$ and $\mathrm{Pb}$ isotopic compositions were measured using the Resonetics S-155-LR $193 \mathrm{~nm}$ Excimer laser ablation system (Australian Scientific Instruments, Fyshwick, Australia) connected to an Agilent 7700x quadrupole Inductively Coupled Plasma -Mass Spectrometer (Agilent Technologies, Santa Clara, United Stated) in the Department of Earth Sciences at the University of New Brunswick, following the procedure outlined by McFarlane and Luo (2012) and Archibald et al. (2013). Data reduction was done in-house using Iolite software (Paton et al. 2011) to process the laser output into data files, and further reduced for U-Pb geochronology using VizualAge (Petrus and Kamber 2012). VizualAge outputs include uncorrected U-Pb ratios which were used to calculate ${ }^{204} \mathrm{~Pb}$-based corrections (Anderson 2002) and ${ }^{208} \mathrm{~Pb}$-based corrections. Data were filtered using ${ }^{204} \mathrm{~Pb}$ as a monitor. For grains with $<15$ counts per second $204 \mathrm{~Pb}$, data are uncorrected; for grains where the $\%$ error on the ${ }^{204} \mathrm{~Pb}$ counts per second was between 20 and $50 \%$ we used a ${ }^{208} \mathrm{~Pb}$ based correction (Petrus and Kamber 2012), and for grains where the $\%$ error on the ${ }^{204} \mathrm{~Pb}$ counts per second was $<20 \%$ we used a ${ }^{204} \mathrm{~Pb}$-based correction (Anderson 2002). After these corrections were applied, data were sorted by $\%$ concordance $\left({ }^{206} \mathrm{~Pb} /{ }^{238} \mathrm{U}\right.$ vs. $\left.{ }^{207} \mathrm{~Pb} /{ }^{235} \mathrm{U}\right)$, and by the $\%$ of radiogenic $\mathrm{Pb}$ in the grains as calculated using VizualAge $(\mathrm{Pb} *$ in Tables 1 and $\mathrm{S} 1)$. Concordia ages were calculated for clusters of three or more near-concordant points using Isoplot v3.75 and 4.15 (Ludwig 2003 rev. 2012), using as many grains as possible that fit the criteria for inclusion in concordia calculations. Data points included in the Concordia calculations and reported here are 
based on grains that are 99 to $100 \%$ concordant (in one case $99-101 \%$ ), and are uncorrected for common $\mathrm{Pb}(204 \mathrm{~Pb}$ cps $<15)$. Instances where grains were chosen outside of these criteria are discussed individually in the subsequent section. We specifically chose to have conservative standards for selecting grains to include in Concordia calculations in order to make use of the most concordant data available (Table 1), as is the standard practice in U-Pb geochronology. Concordia plots for these selected data are presented in Figures 4 and 5; plots showing all of the analytical data are presented in Figure S1 in the Supplementary Data. All analytical data for the samples are included in Supplementary Data Table S1.

Results

Sample LS14-006 is medium-grained, equigranular granodiorite from the Rigwash Brook granodiorite south of Grand Falaise (Fig. 2). Zircon grains analysed from this sample are euhedral with bipyramidal terminations and up to $\sim 150 \mu \mathrm{m}$ in length. Oscillatory zoning is visible in cathodoluminescence in most of the grains. Fifty-four analyses were completed on 38 zircon grains, including 17 centre-rim pairs. After corrections, data points for this sample spread out along concordia between ca. $600 \mathrm{Ma}$ and $520 \mathrm{Ma}$, interpreted here as evidence that the sample likely underwent $\mathrm{Pb}$ loss after crystallization (Fig. S1a, Supplementary Data). For this sample the only uncorrected data that are close to concordant are 5 analyses from grain centres. These 5 analyses produced a concordia age of $566.7 \pm 4.6 \mathrm{Ma}$ (Fig. 4a; Table 1), interpreted here as the crystallization age for the sample. Even though these data show very slight reverse discordance (100.3-100.7\%), the calculated concordia age overlaps within error with that calculated using other near-concordant grain centers, as well as with the weighted mean of single spot ages at 566.0 $\pm 4.9 \mathrm{Ma}$. When using all the data from samples where centre analyses are more than 98\% concordant (including 5 that have an Anderson correction applied) the calculated concordia age is 559.9 $\pm 2.7 \mathrm{Ma}$. This sample 
also contains two older near-concordant grains that have an overlapping concordia age of 650.7 $\pm 9.7 \mathrm{Ma}$, and are interpreted as inherited.

Sample LS14-029 is coarse-grained to megacrystic biotite-muscovite monzogranite from the Pembroke Lake unit in the southern part of the map area (Fig. 2). The 22 analyzed zircon grains are mostly euhedral to subhedral and 75 to $>100 \mu \mathrm{m}$ in length. Oscillatory zoning is visible in cathodoluminescence in most of the grains. Eight overlapping concordant grains produce a concordia age of $567.3 \pm 3.3 \mathrm{Ma}$ (Fig. $4 \mathrm{~b}$; Table 1). This age is interpreted as the crystallization age of the sample and overlaps the weighted mean age of 566.3 $\pm 4.2 \mathrm{Ma}$ for the single spots. One nearconcordant grain in this sample with a concordia age of $1251 \pm 14 \mathrm{Ma}$ is interpreted as inherited.

Sample CW14-124 is medium-grained equigranular tonalite collected along the Cabot Trail from the Canadian Brook tonalite unit (Fig. 2). Most zircon grains are clear with minor inclusions and some have bipyramidal terminations. Oscillatory zoning is visible in cathodoluminescence in most of the grains. One hundred and thirty-three analyses were obtained on 92 zircon grains including 41 centre-rim analyses. Eight overlapping near-concordant grains produce a concordia age of $489.8 \pm 3.2 \mathrm{Ma}$ (Fig. 4c; Table 1) which is interpreted as the crystallization age of the sample. This age overlaps with the weighted mean of spot ages at $487.4 \pm 2.6 \mathrm{Ma}$.

Sample CW15-145 from the Chéticamp River tonalite is medium grained and equigranular. Zircon grains in this sample are clear and euhedral, with oscillatory zoning visible in cathodoluminescence. Seventeen near-concordant grains produce a calculated concordia age of $483.8 \pm 4.1 \mathrm{Ma}$ (Fig. 4d; Table 1), which overlaps with the weighted mean age of spot ages at 481.0 $\pm 6.2 \mathrm{Ma}$. The age of $483.8 \pm 4.1 \mathrm{Ma}$ is interpreted to be the igneous crystallization age of the rock.

Sample CW15-020A from the Upper Fisset Brook quartz diorite (Fig. 2) is coarse-grained, and equigranular. This sample has abundant zircon grains with lengths from $10 \mu \mathrm{m}$ to $100 \mu \mathrm{m}$. Most 
of the grains are acicular with bipyramidal terminations and oscillatory zoning is visible in cathodoluminescence in most of the grains. Twenty-one near-concordant grains out of 60 analyzed produce a concordia age of $481.6 \pm 1.8 \mathrm{Ma}$ (Fig. 4e; Table 1). This age is interpreted as the crystallization age of the sample and overlaps within error with the weighted mean age of $484.7 \pm$ 3.1 Ma for the single spots.

Sample LS14-060 consists of medium-grained, sub-porphyritic quartz diorite from the Lavis Brook quartz diorite unit (Fig. 2). Two populations of zircon grains were analysed from this sample; large $(>250 \mu \mathrm{m}$ in length) euhedral grains with bipyramidal terminations and small $(<250 \mu \mathrm{m}$ in length) stubby euhedral grains with bipyramidal terminations. Oscillatory zoning is visible in cathodoluminescence in most of the grains. Forty-six analyses were completed on 40 zircon grains, including 3 centre-rim pairs. Twelve near-concordant grains produce a concordia age of $440.0 \pm 1.6$ Ma (Fig. 5a; Table 1). This age is interpreted as the crystallization age of the quartz diorite, and overlaps the weighted mean age of $439.5 \pm 1.6$ Ma for the single spots.

Sample LS14-019 from the MacLean Brook granodiorite (Fig. 2) is medium-grained, subporphyritic granodiorite with subhedral plagioclase. The analyzed zircon grains are mostly euhedral with bipyramidal terminations and $>150 \mu \mathrm{m}$ in length. Most grains are clear and have oscillatory zoning. Seventy-six analyses were obtained on 43 zircon grains, including 33 centre-rim analyses. Seventeen near-concordant grains produce a concordia age of $442.4 \pm 2.0 \mathrm{Ma}$ (Fig. 5b; Table 1) which is interpreted as the igneous crystallization age of the sample. This age overlaps with the weight mean spot ages of $438.2 \pm 2.2 \mathrm{Ma}$.

Sample CW15-014A is coarse-grained, equigranular alkali-feldspar granite from the cliff section above the talus slope at Grand Falaise and is part of the Grand Falaise alkali-feldspar granite unit (Fig. 2). This sample has mostly small $<20 \mu \mathrm{m}$ to $50 \mu \mathrm{m}$ zircon grains. Most had euhedral crystal shapes, with bipyramidal terminations. Oscillatory zoning is visible in cathodoluminescence 
in most of the grains. Eleven near-concordant grains produce a concordia age of $427.9 \pm 2.1 \mathrm{Ma}$ (Fig. 5c; Table 1) which is interpreted as the igneous crystallization age of the sample. This age overlaps with the weight mean spot ages of $426.3 \pm 3.1 \mathrm{Ma}$.

Sample CW14-121 is fine- to medium-grained, equigranular syenogranite collected from the French Mountain syenogranite along the Cabot Trail (Fig. 2). The analyzed zircon grains are small ( $<50 \mu \mathrm{m}$ in length) and mostly elongate and showed only very faint oscillitory zoning in cathodoluminescence. Nineteen analyses were obtained on 19 zircon grains. The ${ }^{204} \mathrm{~Pb}$ counts per second ranged from 500 to 3400 , indicating that this sample contains significant common $\mathrm{Pb}$. Hence, all of the data from this sample had a common Pb-correction applied (Anderson 2002, as used in McFarlane and Luo 2012) (see Figure S1, Supplementary Data). In this sample the error on the ${ }^{207} \mathrm{~Pb} /{ }^{235} \mathrm{U}$ ratio was also used to filter the corrected data because several had errors $>20 \%$. Using only the 5 overlapping near-concordant grains produces a concordia age of $366.5 \pm 3.1 \mathrm{Ma}$ (Fig. 5d; Table 1) which is interpreted as the igneous crystallization age of the sample and overlaps with the weight mean spot ages of $368.4 \pm 3.7 \mathrm{Ma}$.

\section{Geochemical Characteristics}

Whole-rock chemical analyses are available for 98 samples from the ten plutonic units included in this study (Supplementary Data Table S2). As is the case for field relations and petrographic characteristics, the chemical characteristics alone are not definitive in indicating which plutons may be related. However, when viewed in combination with the ages presented above, the plutons show chemical similarities and differences which suggest division into 5 plutonic suites, as described below.

Rigwash Brook granodiorite, Farm Brook granodiorite, and Pembroke Lake monzogranite 
Silica contents in analyzed samples from the Rigwash Brook and Farm Brook units range from about 65 to $72 \%$, whereas the Pembroke Lake monzogranite samples have mainly higher silica, from 72-75\%, as illustrated in Figure 6. Two granodioritic samples from the Pembroke Lake pluton have lower silica and are similar to the granodioritic Rigwash Brook and Farm Brook samples. Taken together, these 3 plutons show chemical trends consistent with crystal fractionation of plagioclase and ferromagnesian minerals, as illustrated by plots of $\mathrm{TiO}_{2}, \mathrm{Al}_{2} \mathrm{O}_{3}, \mathrm{Fe}_{2} \mathrm{O}_{3}{ }^{\mathrm{t}}$ and $\mathrm{K}_{2} \mathrm{O}$ against $\mathrm{SiO}_{2}$ (Fig. 6a-d). The $\mathrm{K}_{2} \mathrm{O}$ data are more scattered, with higher $\mathrm{K}_{2} \mathrm{O}$ in samples with more abundant interstitial and megacrystic microcline, although varying extent of alteration has also likely affected the more mobile elements. On the normative mineralogy classification diagram of Streckeisen and LeMaitre (1978), the samples range from granodiorite through to alkali-feldspar granite, consistent with their range in modal and chemical composition, and display a calc-alkalic to calcic trend (Fig. 6e). They also display a calc-alkalic trend on the MALI diagram (Fig. 7a) and plot on the magnesian field on the $\mathrm{FeO} /(\mathrm{FeO}+\mathrm{MgO})$ diagram (Fig. 7b). Samples with more than $65 \% \mathrm{SiO}_{2}$ plot in the volcanic-arc field on the $\mathrm{Rb}$ vs $\mathrm{Y}+\mathrm{Nb}$ tectonic setting discrimination diagram for felsic rocks (Fig. 7c) and in the continental arc and continental collision fields on the A/NK vs A/CNK diagram (Fig. 7d). On the modified Pearce et al (1984) Nb-Y diagram of Hildebrand and Whalen (2015), the samples plot in the slab-failure granite field (Fig. 7e). According to Hildebrand and Whalen (2015), slab failure requires collisional events, typically arc-continent, and hence is evidence for multiple complex accretion events.

Chondrite-normalized REE patterns have similar shapes in samples from all three units, consistent with a comagmatic relationship (Fig. 8a, b, c). They show enrichment in light rare-earth elements (LREE) relative to heavy rare-earth elements (HREE), as indicated by La/Lu (chondritenormalized) ratios ranging from about 25 to 5 . The LREE enrichment as indicated by La/Lu ratio does not show correlation with $\mathrm{SiO}_{2}$ content (Fig. 8h), but total REE content does, with samples 
higher in $\mathrm{SiO}_{2}$ tending to have lower REE abundance (Fig. 8g). A pattern of decreasing REE abundance can be explained by removal of REE-bearing minerals present as inclusions during fractionation of ferromagnesian minerals, in this case likely epidote, apatite, and zircon. The HREE show slightly concave shapes, consistent with amphibole and titanite fractionation (e.g., Hanson 1980). Weak negative and slight positive europium (Eu) anomalies are apparent in some samples, consistent with minor plagioclase accumulation or fractionation. Fractionation of apatite could also reduce the magnitude of the negative Eu anomaly caused by feldspar fractionation (Hanson 1980).

Canadian Brook tonalite, Chéticamp River tonalite, and Upper Fisset Brook quartz diorite

Samples from the Canadian Brook and Chéticamp River tonalite units have similar and relatively small ranges in $\mathrm{SiO}_{2}$ values between about 63 and 67\%, overlapping with but mainly lower than those from the Rigwash Brook and Farm Brook granodiorite units (Fig. 6). The tonalite samples tend to lie along the trend defined by the granodiorite units, but tend to have lower $\mathrm{K}_{2} \mathrm{O}$ (Fig. 6d). In normative mineral classification, they mainly plot in the tonalite and granodiorite fields but some plot in the monzogranite and syenogranite fields related to variations in $\mathrm{K}_{2} \mathrm{O}, \mathrm{CaO}$, and $\mathrm{Na}_{2} \mathrm{O}$ contents likely linked to alteration. As a result, the MALI parameter also shows wide distribution (Fig. 7a). With two exceptions, these samples are generally more magnesian than the Farm Brook and Rigwash Brook granodiorite samples (Fig. 7b). However, the Rb vs Y+Nb diagram indicates a similar volcanic-arc tectonic setting (Fig. 7c), as does the ANK-ACNK diagram (Fig. 7d). In contrast to the ca. 567 Ma plutons, the tonalitic pluton samples plot in the arc field on Figure 7e.

Samples from the Upper Fisset Brook quartz diorite units have lower $\mathrm{SiO}_{2}$ than the tonalitic units, ranging from 50 to $58 \%$. However, a tonalite sample from the Upper Fisset Brook unit has $\mathrm{SiO}_{2}$ content similar to the Canadian Brook and Chéticamp River tonalite samples, and is generally 
similar in other chemical characteristics as well, although it plots in the quartz monzonite field in terms of normative mineralogy (Fig. 6e) as a result of relatively high $\mathrm{K}_{2} \mathrm{O}$ (Fig. 6d) combined with high $\mathrm{Na}_{2} \mathrm{O}$ and low $\mathrm{CaO}$. The remaining Upper Fisset Brook samples generally lie along linear trends with the tonalite samples, but with a gap in $\mathrm{SiO}_{2}$ between about 58 and 63\% (Fig. 6a-d). They plot in the diorite and quartz diorite fields in the normative mineral classification (Fig. 6e), and are mainly calc-alkalic and magnesian (Fig. 7a-b). With the exception of the tonalite sample, they are too mafic to plot on the $\mathrm{Rb}-\mathrm{Y}+\mathrm{Nb}, \mathrm{ANK}-\mathrm{ACNK}$, and $\mathrm{Nb}-\mathrm{Y}$ discrimination diagrams, but other discrimination diagrams such as Th-Hf-Nb (Fig. 7f) indicate calc-alkalic affinity and a convergent margin setting.

The chondrite-normalized REE patterns for samples from the 3 units are similar, with lower total REE abundance in the tonalitic samples compared to the dioritic samples (Fig. 7d). Total REE abundance is much lower than in the Farm Brook and Rigwash Brook granodioritic samples with similar $\mathrm{SiO}_{2}$ contents (Fig. 8g), and the patterns are flatter, with $\mathrm{La} / \mathrm{Lu}(\mathrm{N})$ ratios mainly less than 5 (Fig. 8h). Most samples show slight negative Eu anomalies, but the dioritic samples with highest total REE show larger negative Eu anomalies (Fig. 8d).

\section{Lavis Brook quartz diorite and MacLean Brook granodiorite}

The Lavis Brook and MacLean Brook plutons are a bimodal suite, based on the co-mingled relations observed in the field and their identical ages. The bimodality is reflected in the silica contents which range from 50-62\% in the Lavis Brook samples and cluster around $67 \%$ in the MacLean Brook granodiorite samples. The Lavis Brook samples also show spread in other elements, as exemplified by $\mathrm{TiO}_{2}, \mathrm{Al}_{2} \mathrm{O}_{3}, \mathrm{Fe}_{2} \mathrm{O}_{3}{ }^{\mathrm{t}}$, and $\mathrm{K}_{2} \mathrm{O}$ (Fig. 6a-d). The classification based on normative minerals also shows wide variation, including tonalite, quartz diorite, quartz monzodiorite, and monzodiorite (Fig. 6e). The MALI diagram also shows wide variation, although 
mainly calc-alkalic (Fig. 7a). A narrow range in $\mathrm{MgO} / \mathrm{FeO}$ is apparent on Figure $7 \mathrm{~b}$ where all samples are magnesian. The chemical characteristics of the Lavis Brook quartz diorite are consistent with origin at a convergent continental margin (e.g., Fig. 7f).

The MacLean Brook granodiorite samples overlap in $\mathrm{SiO}_{2}$ with granodioritic and tonalitic samples from older units (Fig. 6). However, compared to the Farm Brook and Rigwash Brook granodiorite samples with similar $\mathrm{SiO}_{2}$, they show chemical differences such as lower $\mathrm{Al}_{2} \mathrm{O}_{3}$ and higher $\mathrm{K}_{2} \mathrm{O}$ (Fig. 6b, d). They also have mainly high MALI (Fig. 7a) and low $\mathrm{FeO} /(\mathrm{FeO}+\mathrm{MgO})$ (Fig. 7b). The MacLean Brook granodiorite apparently formed in a volcanic-arc setting (Fig. 7c, d), consistent with the characteristics of the comagmatic Lavis Brook quartz diorite. But like the ca. 567 Ma plutons, its chemical characteristics are consistent with a slab-failure setting (Fig. 7e), involving collision rather than solely subduction (Hildebrand and Whalen 2015).

The Lavis Brook quartz diorite and MacLean Brook granodiorite samples display similar chondrite-normalized REE pattern (Fig. 8e). Total REE abundance is higher than in the samples from the tonalitic units and the Upper Fisset Brook quartz diorite (Fig. 8g) and the patterns show moderate enrichment in LREE (Fig. 8h). Weak negative Eu anomalies suggest only minor plagioclase fractionation. The flat to slightly concave HREE patterns in these units is consistent with the presence of hornblende, and also suggests derivation from the shallow mantle, as a deeper, garnet-lherzolite mantle source is linked to HREE depletion (Hanson 1980).

\section{Grand Falaise alkali-feldspar granite}

The Grand Falaise alkali-feldspar granite samples have high silica contents (ca. 75-76\%). Although they overlap with the highest silica Pembroke Lake monzogranite samples, they show numerous other chemical differences from those samples, such as higher $\mathrm{TiO}_{2}$, lower $\mathrm{Al}_{2} \mathrm{O}_{3}$, higher $\mathrm{Fe}_{2} \mathrm{O}_{3}$, and mainly higher $\mathrm{K}_{2} \mathrm{O}$ (Fig. 6a-d). Their normative mineralogy plots in the alkali-feldspar 
granite field (Fig. 6e). They are alkali-calcic (Fig. 7a), and most are ferroan (Fig. 7b). They plot in the post-collisional granite field on the high $\mathrm{Y}+\mathrm{Nb}$ side of the volcanic-arc field on the granite discrimination diagram (Fig. 7c) and in the post-orogenic granite field on the ANK-ACNK diagrams (Fig. 7d). The Grand Falaise granite is the only Chéticamp belt pluton with characteristics of A-type granite such as high $\mathrm{Zr}$ and $\mathrm{Na}_{2} \mathrm{O}+\mathrm{K}_{2} \mathrm{O}$ relative to $\mathrm{Ga} / \mathrm{Al}$ ratio (Figs. 7e, 9a-c). The chondrite-normalized REE patterns differ from those of any of the other units, in particular the high abundance of HREE and strong negative Eu anomalies (Fig. 8f). The high HREE result in relatively low $\mathrm{La} / \mathrm{Lu}(\mathrm{N})$ ratios (Fig. 8h), even though the samples show LREE enrichment.

\section{French Mountain syenogranite}

Two samples from the French Mountain syenogranite have about $77 \% \mathrm{SiO}_{2}$, similar to the Grand Falaise alkali-feldspar granite samples. They also show similarities to the Grand Falaise samples in their low abundances of $\mathrm{TiO}_{2}, \mathrm{Al}_{2} \mathrm{O}_{3}$, and $\mathrm{Fe}_{2} \mathrm{O}_{3}$ and high $\mathrm{K}_{2} \mathrm{O}$, but they plot in the syenogranite field in terms of normative mineralogy (Fig. 6e) and have lower Y+Nb (Fig. 7c). Although they have high Fe relative to Mg (Figs. 7b; 9a), they do not have other characteristics of A-type granite (Figs. 7e, 9a-c). Like the ca. 567 Ma and 440 Ma plutons, their chemical characteristics suggest that they formed in a complex collisional tectonic setting (Fig. 7e).

The chondrite-normalized REE pattern for the French Mountain syenogranite samples is distinctly different from that of the Grand Falaise unit, with large depletion in the HREE and slight positive Eu anomaly (Fig. 8f). It is somewhat similar to that for the most evolved (high-silica) samples from the much older Pembroke Lake monzogranite (Fig. 8c).

\section{Sm-Nd Isotopic Data}


Calculated $\varepsilon_{\mathrm{Nd}}$ values (Fig.10) are similar for samples from the Farm Brook $(\mathrm{n}=2)$, Rigwash Brook, and Pembroke Lake units, with slightly negative values potentially indicating a relatively young and juvenile crustal source, or more likely (given the overall chemical characteristics and tectonic setting) crustal contamination of a mantle-derived magma. In contrast, $\varepsilon_{\mathrm{Nd}}$ values for samples from the Canadian Brook tonalite, MacLean Brook granodiorite, and Lavis Brook quartz diorite are positive, indicating that these units are derived from juvenile sources and had relatively short crustal residency time.

Neodymium model ages for the samples in this study range from 810 to $1480 \mathrm{Ma}$, with the youngest ages from the Lavis Brook quartz diorite and MacLean Brook granodiorite units, and the oldest from the Grand Falaise, Pembroke Lake and Upper Fisset Brook units. As these ages are older than the U-Pb (zircon) ages obtained in the present study, they indicate that the units likely formed from recycled or "rejuvenated" rocks (Faure and Mensing 2005), or experienced contamination from older crustal rocks. Such characteristics are typical of Ganderian plutons (Kerr et al. 1995; Barr et al. 1998; Samson et al. 2000), and more detailed discussions of the regional implications of the data are included in those publications.

\section{Discussion}

Although it was previously recognized that the Chéticamp belt of plutons contains a variety of rock types and not all are likely to be of Precambrian age (Barr et al. 1986, 1992), this study has shown that the plutonic history of the area is both more protracted and more complex than expected, with a 200 million-year history of episodic magmatism (Fig. 11).

The oldest dated plutons are Rigwash Brook and Pembroke Lake, with ages of ca. $567 \mathrm{Ma}$ (Figs. 2, 11). This age is older than the age of 550 \pm 8 Ma reported by Jamieson et al. (1986) but that age was determined from multi-grain fractions before more modern techniques of in situ analysis, 
single-grain analysis, or chemical abrasion were developed. Although the Farm Brook granodiorite has not yet been dated, its petrographic and chemical similarity to the ca. 567 Ma Rigwash Brook granodiorite suggests that they are part of the same magmatic episode, and likely part of the same pluton, although they are now geographically separate (Fig. 2). The larger chemical data base now available further supports and strengthens the conclusion of Barr et al. (1986) that the Farm Brook pluton, approximately equivalent to the biotite grandodiorite and megacrystic granodioritic units of their "Chéticamp pluton", is comagmatic with the Pembroke Lake muscovite-biotite monzogranite. This interpretation is further supported by the recognition of granodioritic components in the Pembroke Lake pluton which are similar to granodiorite in the Farm Brook and Rigwash Brook plutons. Distinctive petrographic features such as the presence of relict magmatic epidote and the presence of large microcline crystals overgrown on earlier-crystallizing phases are strong evidence of cogenetic parent magma, although the significance of those textural features requires further study.

The host rocks for ca. 567 plutonic units in the southern part of the Chéticamp belt (Stewart Brook Formation) closely resemble metamorphic units of the Bras d'Or terrane and hence are assigned to the George River Metamorphic Suite (Fig. 1, 2). Like the Rigwash Brook, Farm Brook, and Pembroke Lake plutons, the voluminous ca. 570-550 Ma plutons of the Bras d'Or terrane have characteristics indicating origin in a continental margin arc located on the Ganderian margin of the Iapetus Ocean. The complexity of subsequent tectonic activity on-going into the Carboniferous (e.g. Waldron et al. 2015) make specific correlations between these now geographically separated areas, and the mechanisms by which they achieved their present locations, difficult to interpret.

These ca. 567 Ma plutonic units in the Chéticamp area are similar in age and tectonic setting to a suite of ca. 565-563 Ma bimodal volcanic rocks (Sandy Brook Group) and co-magmatic plutonic units (Crippleback Lake, Valentine Lake, and Lemottes Lake plutons) which occur along 
the western margin of Ganderia in the Exploits Subzone of central Newfoundland (Rogers et al. 2006; van Staal 2007). Those units similarly display continental arc-like geochemical signatures and have negative $\varepsilon_{\mathrm{Nd}}$ values characteristic of Ganderia (Rogers et al. 2006). They may be related to fault-bounded areas of coeval igneous rocks in the Hermitage Flexure in southern Newfoundland (Lin et al. 2007). Like rocks of similar ages in the Bras d'Or and Brookville terranes, these rocks have been considered to be part of Ganderian basement (e.g., van Staal et al. 1996; Barr et al. 1998; van Staal and Barr 2012; White et al. 2016a).

The Canadian Brook tonalite, dated at $490 \mathrm{Ma}$, is petrographically and chemically similar to the ca. 484 Ma Chéticamp River tonalite, ages of which overlap within error (Fig. 4c, d), and to tonalitic components in the Upper Fisset Brook quartz diorite which yielded a similar age of ca. 482 Ma (Fig. 4e). These ca. 485 Ma plutons, unlike the ca. 567 Ma plutons, appear to have intruded the Jumping Brook Metamorphic Suite, for which a Cambrian maximum depositional age of ca. 530 Ma has been now been confirmed (Lin et al. 2007; White et al. 2016b). These results provide an explanation for the long-standing conundrum about the Chéticamp plutonic belt, as to whether or not the plutonic rocks are younger than the JBMS and hence intruded them, or whether they are older and everywhere in faulted contact with the JBMS, the answer being that both are correct. The ages of ca. 490-482 Ma for these plutonic rocks coincides with the age suggested for the Penobscot arc, identified in the Exploits subzone in Newfoundland and New Brunswick (e.g., van Staal, 2007; van Staal and Barr 2012; Zagorevski et al. 2007, 2010). We suggest that the MORB-like mafic volcanic rocks and associated turbiditic sedimentary rocks of the Faribault Brook unit of the Jumping Brook Metamorphic Suite (e.g. Connors 1986; Tucker 2011) may represent the Penobscot ocean floor rocks deposited in a back-arc basin in Ganderia prior to the formation of the Penobscot arc (Pollock 2007; van Staal and Barr 2012). The overlying quartz-rich units of the Dauphine and Barren Brook formations may thus represent the older parts of the Gander and Miramichi groups, 
characteristic of Ganderia in Newfoundland and New Brunswick, respectively, although admittedly, only very small remnants of this complex story are preserved in the study area compared to Newfoundland and New Brunswick.

After a gap of about 45 million years in the rock record in the Chéticamp area, the Lavis Brook quartz diorite and MacLean Brook granodiorite record evidence of renewed subductionrelated igneous activity. Although the preserved material appears bimodal, the same is true for volcanic and associated plutonic rocks of Silurian age elsewhere in the Aspy terrane (Barr and Jamieson 1991; O’Neil 1998). The latter rocks have been correlated with the La Poile area of southwestern Newfoundland and the Kingston terrane of southern New Brunswick (Lin et al. 2007; van Staal 2007). These arc-type rocks have been interpreted to have formed in a northwest-dipping subduction zone, possibly related to the joining of Avalonia to Ganderia (e.g. van Staal and Barr 2012), and consistent with their slab-failure chemical signatures (Hildebrand and Whalen 2015). The position of the Chéticamp area and Mabou Highlands to the west of the Aspy terrane has led to a suggested correlation with the New River terrane of southern New Brunswick, which occupies a similar position with respect to the Kingston arc (Barr et al. 2002). Felsic volcanic rocks of the Kingston terrane have yielded $\mathrm{U}-\mathrm{Pb}$ (zircon) ages of $436 \pm 3 \mathrm{Ma}, 437 \pm 3 \mathrm{Ma}$, and $442 \pm 6 \mathrm{Ma}$, and co-magmatic felsic and minor dioritic plutonic rocks have yielded very similar U-Pb (zircon) ages of $436 \pm 2 \mathrm{Ma}, 435 \pm 5 \mathrm{Ma}$, and $437 \pm 10 \mathrm{Ma}$ (Doig et al. 1990; Barr et al. 2002; McLeod et al. 2003). These ages are close to those of the MacLean Brook and Lavis Brook units in the Chéticamp area (Fig. 11). Rocks of the Kingston terrane are also interpreted to represent a calc-alkaline, continental-margin collisional volcanic arc (Barr et al. 2002).

The close association of the Neoproterozoic rocks in the Chéticamp belt and the ca. $440 \mathrm{Ma}$ Lavis Brook and MacLean Brook plutons is significant. The latter plutons have characteristics suggesting that they are linked to Ordovician-Silurian magmatism in the Aspy terrane, although 
now separated from that area by a major fault zone. This link indicates that the model of Barr et al. (1995) and Price et al. (1999) in which the Chéticamp belt is part of the older infrastructure of the Aspy volcanic arc is a reasonable possibility. However, the interpretation still has problems, because the Chéticamp belt overall appears to have not been affected by the regional metamorphism and deformation that characterizes units of similar age in the Aspy terrane. Furthermore, Reynolds et al. (1989) showed that muscovite in the part of the Chéticamp Pluton now named Pembroke Lake retains a cooling age of $545 \pm 5 \mathrm{Ma}$, and shows no evidence for the ca. $440 \mathrm{Ma}$ magmatic event recorded in the Lavis Brook and MacLean Brook plutons, nor for the deformational and thermal events which widely affected the Aspy terrane, as evidenced by mainly Devonian biotite and hornblende ages (Reynolds et al. 1989; Price et al. 1999). A further link with the Bras d'Or terrane is provided by the presence of a ca. $440 \mathrm{Ma}$ arc-type dioritic unit in association with the Neoproterozoic plutons in the Creignish Hills of the Bras d'Or terrane (Keppie et al. 1998b), although any original relations among these now widely separated rock units is obscured by major faults and Carboniferous sedimentary cover (Fig. 1).

At Grand Falaise, the Grand Falaise alkali-feldspar granite and its host rocks of the ca. 567 Ma Rigwash Brook granodiorite have been thrust over ca. 375 Ma rocks of the Fisset Brook Formation, while still carrying Fisset Brook Formation rocks unconformably on top of it. The relationship of these allochthonous rocks to the Jumping Brook Metamorphic Suite and associated ca. $485 \mathrm{Ma}$ and $366 \mathrm{Ma}$ plutonic rocks is not yet clear. The near-horizontal structures that characterize the Jumping Brook Metamorphic Suite (Jamieson and Craw 1983; Craw 1984; Tucker 2011) attest to the structural complexity of the area. Yet, these structural features are not displayed in the plutonic units of this study. The area is dissected by major faults with few constraints on lateral offsets. Units may now be juxtaposed along these faults which were formed in widely 
separated areas and hence experienced different deformational and thermal histories. More detailed mapping and structural studies are needed to further unravel this complex area.

\section{Conclusions}

New U-Pb (zircon) ages have shown that the former "Chéticamp pluton" consists of 10 separate plutons of 5 different ages: Late Neoproterozoic (ca. $567 \mathrm{Ma}$ ), Cambrian-Ordovician (490$482 \mathrm{Ma}$ ), Ordovician-Silurian (442-440 Ma), mid-Silurian (ca. $428 \mathrm{Ma}$ ), and late Devonian (366 Ma). The ca. 567 Ma Rigwash Brook, Pembroke Lake plutons and petrologically similar but undated Farm Brook granodiorite are likely to have been part of a single plutonic unit disrupted by faulting, as were the ca. 490-482 Ma tonalitic to quartz dioritic Canadian Brook, Chéticamp River, and Upper Fisset Brook plutons. The southern part of the plutonic belt (ca. $567 \mathrm{Ma}$ and $440 \mathrm{Ma}$ units) has strong links to both the Aspy and Bras d'Or terranes, based on type and ages of rock units. However, plutons in the northern part of the belt (ca. $485 \mathrm{Ma}$ and ca. $429 \mathrm{Ma}$ units) intruded the Cambrian Jumping Brook Metamorphic Suite, the relationship of which to the rest of the Aspy terrane remains enigmatic.

The recognition of a ca. $567 \mathrm{Ma}$ arc-related magmatic event along the western margin of the Aspy terrane that is coeval with and isotopically similar to magmatism in the Sandy Brook Group and Crippleback Intrusive Suite suggests a link between the Chéticamp area and the Exploits Subzone in Newfoundland. This correlation strengthens the interpretation that these units as well as similar units in the Bras d'Or terrane represent basement to the subsequent Iapetus-related volcanism confirming links with the peri-Gondwanan microcontinent of Ganderia. The previously unrecognized ca. 490-482 Ma magmatic event may be direct evidence in Cape Breton Island for plutonic activity in the Penobscot arc. Hence these results place western Cape Breton Island in a new regional perspective by demonstrating the presence of Cambrian-Ordovician Ganderian rocks 
with ages, rock types, and tectonic settings similar to some of those in the Exploits Subzone of the northern Appalachian orogen.

\section{Acknowledgements}

This paper is derived in part from the MSc thesis project of the first author, supplemented by additional mapping, sampling, petrological work, and U-Pb dating by the other authors. We thank Jonathan Shute for his able assistance in the field work, and Travis McCarron for sharing his insights as a result of his field work in the northern part of the plutonic belt. Alan Macdonald, Becky Jamieson, and Rob Raeside provided geological insights and field information over many decades of work in the Cape Breton Highlands. We thank Alan Dickin for his assistance with the Sm-Nd analyses. We thank Brandon Boucher and Chris McFarlane for assisting D. van Rooyen with the $\mathrm{U}-\mathrm{Pb}$ dating at the University of New Brunswick and for providing invaluable advice in processing and interpreting the age data. We thank journal reviewers Dawn Kellett and Joe Whalen, as well as associate editor Marie-Claude Williamson, for their helpful comments which led to significant improvements in the manuscript. This work was funded in part by a NSERC Discovery Grant to Sandra Barr, an Acadia Graduate Award to Lisa Slaman, and a Research Policy Grant from Cape Breton University to Deanne van Rooyen.

\section{References}

Anderson, T. 2002.Correction of common lead in $\mathrm{U}-\mathrm{Pb}$ analyses that do not report ${ }^{204} \mathrm{~Pb}$. Chemical Geology, 192: 59-79.

Archibald, D.B., Barr, S.M., Murphy, J.B., White, C.E., MacHattie, T.G., Escarraga, E.A., Hamilton, M.A., and McFarlane, C.R.M. 2013. Field relationships, petrology, age, and tectonic 
setting of the Ordovician West Barneys River Plutonic Suite, southern Antigonish Highlands, Nova Scotia, Canada. Canadian Journal of Earth Sciences, 50: 727-745.

Barr, S.M. 1990. Granitoid rocks and terrane characterization: an example from the northern Appalachian Orogen. Geological Journal, 25: 295-304

Barr, S.M., and Jamieson, R.A. 1991. Tectonic setting and regional correlations of OrdovicianSilurian metavolcanic rocks of the Aspy Terrane, Cape Breton Island, Nova Scotia. Canadian Journal of Earth Sciences, 28: 1769-1779.

Barr, S.M., and Hegner, E. 1992. Nd isotopic compositions of felsic igneous rocks in Cape Breton Island, Nova Scotia: implications for petrogenesis and terrane analysis. Canadian Journal of Earth Sciences, 29: 650-657.

Barr, S.M., and Peterson, K. 1998. Field relations and petrology of the Fisset Brook Formation in the Chéticamp area, western Cape Breton Island, Nova Scotia. Atlantic Geology, 34: 121-132.

Barr, S.M., and Raeside, R.P. 1989. Tectono-stratigraphic terranes in Cape Breton Island, Nova Scotia:.implications for the configuration of the northern Appalachian orogen. Geology, 17: $822-825$.

Barr, S.M., Macdonald, A.S., and Blenkinsop, J. 1986. The Chéticamp pluton: a Cambrian granodioritic intrusion in the western Cape Breton Highlands, Nova Scotia. Canadian Journal of Earth Sciences, 23: 1686-1699.

Barr, S.M., Jamieson, R.A., and Raeside, R.P. 1992. Geology, northern Cape Breton Island, Nova Scotia: Geological Survey of Canada Map 1752A, scale 1:100 000.

Barr, S.M., Raeside, R.P., Miller, B.V., and White, C.E. 1995. Terrane evolution and accretion in Cape Breton Island, Nova Scotia. In Current Perspectives in the Appalachian-Caledonian Orogen. Edited by J.P. Hibbard, C.R. van Staal, and P.A. Cawood. Geological Association of Canada, Special Paper 41, pp. 391-407. 
Barr, S.M., Raeside, R.P., and White, C.E. 1998. Geological correlations between Cape Breton Island and Newfoundland, northern Appalachian orogen. Canadian Journal of Earth Sciences, 35: $1252-1270$.

Barr, S.M., White, C.E., and Miller, B.V. 2002. The Kingston terrane, southern New Brunswick, Canada: Evidence for a Silurian volcanic arc. Geological Society of America Bulletin, 114: 964982.

Barr, S.M., White, C.E., Davis, D.W., McClelland, W.C., and van Staal, C.R. 2014a. Infrastructure and provenance of Ganderia: evidence from detrital zircon ages in the Brookville terrane, southern New Brunswick, Canada. Precambrian Research, 246: 358-370.

Barr, S.M., Dehler, S.A., and Zsámboki, L. 2014b. Connecting Cape Breton Island and Newfoundland, Canada: Geophysical modeling of pre-Carboniferous "basement" rocks in the Cabot Strait area. Geoscience Canada, 41: 186-206.

Chappell, B.W., and White, A.J.R. 1992. I- and S-type granites in the Lachlan Fold Belt. Transactions of the Royal Society of Edinburgh. Earth Sciences, 83: 1-26.

Connors, K. 1986. Relationships between the sulphide minerals, metamorphism, and deformation in the Faribault Brook area of the Cape Breton Highlands, Nova Scotia. Unpublished B.Sc. thesis, Dalhousie University, Halifax, NS.

Craw, D. 1984. Tectonic stacking of metamorphic zones in the Chéticamp River area, Cape Breton Highlands, Nova Scotia. Canadian Journal of Earth Sciences, 21: 1229-1244.

Currie, K.L. 1987. Relations between metamorphism and magmatism near Chéticamp, Cape Breton Island, Nova Scotia. Geological Survey of Canada, Paper 85-23, 66p.

Currie, K.L., Loveridge, W.D., and Sullivan, R.W. 1982. A U Pb age on zircon from dykes feeding basal rhyolitic flows of the Jumping Brook complex, northwestern Cape Breton Island, Nova 
Scotia. In Rb-Sr and U-Pb Isotopic Age Studies, Report 5, Geological Survey of Canada, Paper 82 1C, pp. $125-128$

Dallmeyer, R. D., and Keppie, J. D. 1993. ${ }^{40} \mathrm{Ar} /{ }^{39} \mathrm{Ar}$ mineral ages from the southern Cape Breton Highlands and Creignish Hills, Cape Breton Island, Canada: evidence for a polyphase tectonothermal evolution: Journal of Geology, 101: 467-482.

DePaolo, D.J. 1981. Neodymium isotopes in the Colorado front range and crust-mantle evolution in the Proterozoic. Nature 291: 193-196.

Doig, R., Nance, R. D., Murphy, J. B., and Casseday, R. P. 1990. Evidence for Silurian sinistral accretion of Avalon composite terrane in Canada. Journal of the Geological Society, 147: 927930.

Faure, G., and Mensing, T.M. 2005. Isotopes: Principles and Applications. Third Edition. John Wiley \& Sons, Inc. Hoboken, NJ, USA. 897 p.

Frost, B.R, and Frost, C.D. 2008. A geochemical classification for feldspathic igneous rocks. Journal of Petrology, 49: 1955-1969.

Frost, B.R., Barnes, C.G., Collins, W.J., Arculus, R.J., Ellis, D.J., and Frost, C.D. 2001. A geochemical classification for granitic rocks. Journal of Petrology, 42: 2033-2048.

Hanson, G.N. 1980. Rare earth elements in petrogenetic studies of igneous systems. Annual Review of Earth and Planetary Science, 8: 371-406.

Hibbard, J.P., van Staal, C.R., Rankin, D.W., and Williams, H. 2006. Lithotectonic map of the Appalachian Orogen, Canada-United States of America; Geological Survey of Canada, Map 2096A, scale 1: 1500000.

Hildebrand, R.S., and Whalen, J.B., 2015. Arc and slab-failure magmatism in Cordilleran batholiths II - The Cretaceous Peninsular Ranges Batholith of Southern and Baja California, in Stirring 
The Pot, A Celebration of the Career of Paul F. Hoffman, eds., Murphy, J.B., Hildebrand, R.S., and Halverson, G.P., Geoscience Canada Reprint Series 11, p. 239-267.

Jamieson, R.A., and Craw, D. 1983. Reconnaissance mapping of the southern Cape Breton

Highlands- a preliminary report. In Current Research, Part A, Geological Survey of Canada, Paper 83-1A, pp. 263-268.

Jamieson, R.A., van Breemen, O., Sullivan, R.W., and Currie, K.L. 1986. The age of igneous and metamorphic events in the western Cape Breton Highlands, Nova Scotia. Canadian Journal of Earth Sciences, 23: 1891-1901.

Jamieson, R.A., Tallman, P.C., Marcotte, J.A., Plint, H.E., and Connors, K.A. 1987. Geology of the west-central Cape Breton Highlands, Nova Scotia. Geological Survey of Canada, Paper 87-13.

Jamieson, R.A., Tallman, P.C., Plint, H.E., and Connors, K.A. 1989. Geological setting of preCarboniferous mineral deposits in the western Cape Breton Highlands, Nova Scotia. Geological Survey of Canada, Open File 2008.

Johnson, S.C., Fyffe, L.R., McLeod, M.J. and Dunning, G.R., 2011. U-Pb ages, geochemistry, and tectonomagmatic history of the Cambro-Ordovician Annidale Group: a remnant of the Penobscot arc system in southern New Brunswick? Canadian Journal of Earth Sciences, 49:166188.

Keppie, J.D., Dostal, J., Davis, D.W., and Horton, D.A. 1998. Earliest Silurian suprasubduction magmatism in central Cape Breton Island. Atlantic Geology, 34: 113-120.

Kerr, A., Jenner, G.A., and Fryer, B.J. 1995. Sm-Nd isotopic geochemistry of Precambrian to Paleozoic granitoid suites and the deep-crustal structure of the southeast margin of the Newfoundland Appalachians. Canadian Journal of Earth Sciences, 32: 224-245.

LeMaitre, R.W., 1989. A classification of igneous rocks and glossary of terms. Oxford: Blackwell, $193 p$. 
Lin, S. 1992. The stratigraphy and structural geology of the southeastern Cape Breton Highlands National Park and its implications for the tectonic evolution of Cape Breton Island, Nova Scotia, with emphasis on lineations in shear zones. Unpublished Ph.D. Thesis, University of New Brunswick, Fredericton.

Lin, S. 1993. Relationship between the Aspy and Bras d'Or "terranes" in the northeastern Cape Breton Highlands, Nova Scotia. Canadian Journal of Earth Sciences, 30: 1773-1781.

Lin, S. 1995. Structural evolution and tectonic significance of the Eastern Highlands shear zone in Cape Breton Island, the Canadian Appalachians. Canadian Journal of Earth Sciences, 32: 545554.

Lin, S., van Staal, C. R. and Dubé, B. 1994. Promontory-promontory collision in the Canadian Appalachians: Geology, 22: 897-900.

Lin, S., Davis, D.W., Barr, S.M., van Staal, C.R., Chen, Y., and Constantin, M. 2007. U-Pb geochronological constraints on the evolution of the Aspy Terrane, Cape Breton Island: Implications for relationships between Aspy and Bras d'Or terranes and Ganderia in the Canadian Appalachians. American Journal of Science, 307: 371-398.

Ludwig, K.R. 2003, revised 2012. Isoplot 3.75 and 4.15: A Geochronological Toolkit for Microsoft Excel. Berkeley Geochronological Centre Special Publication No. 5.

Lynch, G. 1996. Tectonic burial, thrust emplacement, and extensional exhumation of the Cabot nappe in the Appalachian hinterland of Cape Breton Island, Canada. Tectonics, 15: 94-105. Lynch, J.V.G., and Tremblay, C. 1992. Imbricate thrusting, reverse-oblique shear, and ductile extensional shear in the Acadian Orogen, central Cape Breton Highlands, Nova Scotia. In Current research, part D. Geological Survey of Canada, Paper 92-1D, pp. 91-100. 
Lynch, J.V.G., and Tremblay, C. 1994. Late Devonian-Carboniferous detachment faulting and extensional tectonics in western Cape Breton Island, Nova Scotia, Canada. Tectonophysics, 238: $55-69$.

MacDonald, C.A.K. 1996. Petrography, geochemistry, and structure of the Taylors Barren pluton, Cape Breton Island, Nova Scotia. B.Sc. thesis, Acadia University, Wolfville, N.S.

Macdonald, A.S., and Barr, S.M. 1985. Geology and age of polymetallic mineral occurrences in volcanic and granitoid rocks, St. Anns area, Cape Breton Island, Nova Scotia. In Current Research, Part B, Geological Survey of Canada Paper 85 1B, pp. 117-124.

MacLaren, A.S. 1955. Chéticamp River, Inverness and Victoria Counties, Cape Breton Island, Nova Scotia; Geological Survey of Canada, Preliminary Map 55-36, scale 1 inch to 1 mile.

Maniar, P. D., and Piccoli, P. M. 1989. Tectonic discrimination of granitoids. Geological Society of America Bulletin, 101: 635-643.

McFarlane, C.R.M., and Luo, Y. 2012. Modern analytical facilities: U-Pb geochronology using 193nm Excimer LA-ICP-MS optimized for in situ accessory mineral dating in thin sections. Geoscience Canada, 39: 158-172.

McLeod, M.J., Johnson, S.C., and Krogh, T.E. 2003. Archived U-Pb (zircon) dates from southern New Brunswick. Atlantic Geology, 39: 209-225.

Murphy, J.B. 2002. Geochemistry of the Neoproterozoic metasedimentary Gamble Brook Formation, Avalon terrane, Nova Scotia: Evidence for a rifted-arc environment along the West Gondwanan margin of Rodinia. The Journal of Geology, 110: 407-419.

Nance, R.D., Murphy, J.B., Strachan, R.A., Keppie, J.D., Gutierrez-Alonso, G., Fernandez-Suarez, J., Quesada, C., Linnemann, U., D'lemos, R., and Pisarevsky, S.A. 2008. Neoproterozoic - early Palaeozoic tectonostratigraphy and palaeogeography of the peri-Gondwanan terranes: Amazonian v. West African connections. In The Boundaries of the West African Craton. Edited 
by N. Ennih, N. \& J.-P Lie' Geois. Geological Society, London, Special Publication 297, pp. $345-383$.

O'Neill, M.J. 1996. Geology of the Leonard McLeod Brook area, southern Cape Breton Highlands, Nova Scotia. M.Sc. thesis, Acadia University, Wolfville, N.S.

Paton, C., Hellstrom, J.C., Paul, B., Woodhead, J.D., and Hergt, J.M. 2011. Iolite: Freeware for the visualisation and processing of mass spectrometric data. Journal of Analytical Atomic Spectrometry, 26: 2508-2518.

Pearce, J.A., 1996. Sources and settings of granitic rocks. Episodes 19: 120-125.

Pearce, J.A., Harris, N. W. B., and Tindle, A. G. 1984. Trace element discrimination diagrams for the tectonic interpretation of granitic rocks. Journal of Petrology, 25: 956-983.

Peccerillo, A., and Taylor, S.R., 1976. Geochemistry of the Eocene calc-alkaline volcanic rocks from Kastamonu area, northern Turkey. Contributions to Mineralogy and Petrology, 58: 63-81.

Petrus, J.A. and Kamber, B.S. 2012. VizualAge: A novel approach to laser ablation ICP-MS U-317 $\mathrm{Pb}$ geochronology data reduction. Geostandards and Geoanalytical Research, 36: 247-270.

Pollock, J.C. 2007. The Neoproterozoic-Early Paleozoic tectonic evolution of the peri-Gondwanan margin of the Appalachian orogen: an integrated geochronological, geochemical and isotopic study from North Carolina and Newfoundland. PhD thesis, North Carolina State University, Raleigh, USA.

Price, J., Barr, S.M., Raeside, R.P., and Reynolds, P. 1999. Petrology, tectonic setting, and ${ }^{40} \mathrm{Ar} /{ }^{39} \mathrm{Ar}$ (hornblende) dating of the Late Ordovician-Early Silurian Belle Cote Road orthogneiss, western Cape Breton Highlands, Nova Scotia: Atlantic Geology, 35: 1-17.

Raeside, R. P., and Barr, S.M. 1990. Geology and tectonic development of the Bras d'Or suspect terrane, Cape Breton Island, Nova Scotia. Canadian Journal of Earth Sciences, 27: 1371-1381. 
Reynolds, P.H., Jamieson, R.A., Barr, S.M., and Raeside, R.P. 1989. A ${ }^{40} \mathrm{Ar} /{ }^{39} \mathrm{Ar}$ dating study in the Cape Breton Highlands, Nova Scotia: thermal histories and tectonic implications: Canadian Journal of Earth Sciences, 26: 2081-2091.

Rogers, N., van Staal, C.R., McNicoll, V., Pollock, J., Zagorevski, A., and Whalen, J. 2006. Neoproterozoic and Cambrian arc magmatism along the eastern margin of the Victoria Lake Supergroup: A remnant of Ganderian basement in central Newfoundland? Precambrian Research, 147: 320-341.

Samson, S.D., Barr, S.M., and White, C.E. 2000. Nd isotopic characteristics of terranes within the Avalon zone, southern New Brunswick. Canadian Journal of Earth Sciences, 37: 1039-1052.

Shand, S. J. (1943). The Eruptive Rocks, 2nd edn. New York: John Wiley, 444 pp

Slaman, L. 2015. Petrology and tectonic setting of plutonic rocks in the Chéticamp area, western Cape Breton Island, Nova Scotia, Canada. Unpublished MSc thesis, Acadia University, Wolfville, NS.

Slaman, L., White, C.E., and Barr, S.M. 2014. Preliminary geology and related mineral potential of the Chéticamp area, Cape Breton Island, Nova Scotia. Nova Scotia Department of Natural Resources, Minerals Resource Branch, Open File Illustration 2014-012.

Streckeisen, A., and Le Maitre, R.W. 1979. A chemical approximation to the modal QAPF classification of the igneous rocks. Neues Jahrbuch für Mineralogie Abhandlungen, 136 : 169 206.

Sun, S.-s., and McDonough, W.F. 1989. Chemical and isotopic systematic of oceanic basalts: implications for mantle composition and processes. In Geological Society of London, Special Publications 42, pp. 313-345.

Tucker, M. 2011. Geology and mineral occurrences in the Faribault Brook area, Cape Breton Island, Nova Scotia. M.Sc. Thesis, Acadia University, Wolfville, N.S. 
van Staal, C.R. 1994. The Brunswick subduction complex in the Canadian Appalachians: record of the Late Ordovician to Late Silurian collision between Laurentia and the Gander margin of Avalon. Tectonics, 13: 946-962.

van Staal, C. R. 2007: Pre-Carboniferous metallogeny of the Canadian Appalachians. In Mineral Deposits of Canada: A Synthesis of Major Deposit Types, District Metallogeny, the Evolution of Geological Provinces, and Exploration Methods. Edited by W. D. Goodfellow; Mineral Deposits Division, Geological Association of Canada, Special Publication, no. 5, p. 793-818. van Staal, C.R. and Barr, S.M. 2012. Lithospheric architecture and tectonic evolution of the Canadian Appalachians. In Tectonic Styles in Canada Revisited: the LITHOPROBE perspective. Edited by J.A. Percival, F.A. Cook and R.M. Clowes. Geological Association of Canada Special Paper 49, pp. 41-95.

van Staal, C. R., Sullivan, R. W., and Whalen, J. B. 1996. Provenance and tectonic history of the Gander Margin in the Caledonian/Appalachian Orogen: implications for the origin and assembly of Avalonia. In Avalonian and related peri-Gondwanan terranes of the circum-North Atlantic. Edited by R.D. Nance and M.D. Thompson. Geological Society of America, Special Paper 304, pp. 347-367.

van Staal, C. R., Wilson, R. A., Rogers, N., Fyffe, L.R., Langton, J.P., McCutcheon, S.R., McNicoll, V., and Ravenhurst, C.E. 2003. Geology and tectonic history of the Bathurst Supergroup and its relationships to coeval rocks in southwestern New Brunswick and adjacent Maine - a synthesis. In Massive sulfide deposits of the Bathurst Mining Camp, New Brunswick, and northern Maine. Edited by W.D. Goodfellow, S.R. McCutcheon, and J.M. Peter. Economic Geology Monograph 11, pp. 37-60.

van Staal, C. R., Whalen, J. B., Valverde-Vaquero, P., Zagorevski, A. and Rogers, N. 2009. PreCarboniferous, episodic accretion-related, orogenesis along the Laurentian margin of the 
northern Appalachians. In Ancient orogens and modern analogues. Edited by J. B. Murphy J. D. Keppie, and A. J. Hynes. Geological Society London Special Publication 327, pp. 271-316. Waldron, J.W.F, Barr, S.M., Park, A.F., White, C.E., and Hibbard, J. P. 2015. Late Paleozoic strikeslip faults in Maritime Canada and their role in the reconfiguration of the northern Appalachian orogen. Tectonics, $\mathbf{3 4 :}$ 1-24.

Whalen, J.B., and Frost, C.D. 2013. The Q-ANOR diagram: A tool for the petrogenetic and tectonomagmatic characterization of granitic suites. South-Central Section, Geological Society of America, Austin, Texas, abstract.

Whalen, J.B., Currie, K.L., and Chappell, B.W. 1987. A-type granites: geochemical characteristics, discrimination, and petrogenesis. Contributions to Mineralogy and Petrology, 95: 407-419.

White, C.E., Barr, S.M., Bevier, M.L., and Kamo, S. 1994. A revised interpretation of Cambrian and Ordovician rocks in the Bourinot belt of central Cape Breton Island, Nova Scotia. Atlantic Geology, 30: 123-142.

White, C.E., Barr, S.M., Davis, D.W., Swanton, D.S., Ketchum, J.W.F., and Reynolds, P.H. $2016 a$. Field relations, age, and tectonic setting of metamorphic and plutonic rocks in the Creignish Hills - North Mountain area, southwestern Cape Breton Island, Nova Scotia, Canada. Atlantic Geology, 52: 35-57.

White, C.E., Barr, S.M., van Rooyen, D., Slaman, L.R., and Shute, J.M. 2016b. A revised geological interpretation of the Chéticamp area, western Cape Breton Island, Nova Scotia, Canada. Abstract in Atlantic Geology, 52: 120.

Wood, D. A. 1980. The application of a Th-Hf-Ta diagram to problems of tectonomagmatic classification and to establishing the nature of crustal contamination of basaltic lavas of the British Tertiary volcanic province. Earth and Planetary Science Letters, 50: 11-30. 
Yaowanoiyothin, W., and Barr, S.M. 1991. Petrology of the Black Brook Granitic Suite, Cape Breton Island, Nova Scotia. Canadian Mineralogist, 29: 499-515.

Zagorevski, A., Van Staal, C.R., McNicoll, V. and Rogers, N., 2007. Upper Cambrian to Upper Ordovician peri-Gondwanan island arc activity in the Victoria Lake Supergroup, Central Newfoundland: Tectonic development of the northern Ganderian margin. American Journal of Science, 307(2):.339-370.

Zagorevski, A., van Staal, C. R., Rogers, N., McNicoll, V., Dunning, G. R., and Pollock, J. C. 2010. Middle Cambrian to Ordovician arc-backarc development on the leading edge of Ganderia, Newfoundland Appalachians. In From Rodinia to Pangea: The lithotectonic record of the Appalachian region. Edited by R.P. Tollo, M.J. Batholomew, J.P. Hibbard, and P.M. Karabinos. Geological Society of America Memoir 206, pp.367-396.

Zen, E-An, and Hammarstrom, J.M. 1984. Magmatic epidote and its petrologic significance. Geology, 12: 515-518.

Zen, E-An, and Hammarstrom, J.M. 1988. Plumbing the depth of plutons by magmatic epidotehornblende association: a cautionary review and an example from Round Valley pluton, western 1daho. Geological Society of America, Abstracts and Programs 20, pp. 475-476. 


\section{List of Figures:}

Fig. 1. Simplified geological map of central and northern Cape Breton Island after Barr et al. (1998) showing the location of the Chéticamp plutonic belt. Inset map shows components of the northern Appalachian orogen after Hibbard et al. (2006).

Fig. 2. Geological map of the Chéticamp plutonic belt modified from Barr et al. (1992), Slaman (2015), Slaman et al. (2014), and this study. Locations and ages for dated samples are shown as stars: red, this study; blue, Currie et al. (1982); green, Jamieson et al. (1986).

Fig. 3. Scanning electron microscope images of representative zircon grains shown in backscattered electron mode (left) and cathodoluminescence (right). (a) Grain CW15-145S-47 which produced a ${ }^{206} \mathrm{~Pb} /{ }^{238} \mathrm{U}$ age of $467 \pm 13 \mathrm{Ma}$. (b) Grain CW15-145S-17 which produced a ${ }^{206} \mathrm{~Pb} /{ }^{238} \mathrm{U}$ age of $486 \pm 15 \mathrm{Ma}$. (c) Grain CW15-020B-38 which produced a ${ }^{206} \mathrm{~Pb} /{ }^{238} \mathrm{U}$ age of $476 \pm 18 \mathrm{Ma}$. (d) Grains CW15-020B-16 (grain on the left) and CW15-020B-15 (grain on the right) which produced ${ }^{206} \mathrm{~Pb} /{ }^{238} \mathrm{U}$ ages of $476.6 \pm 8 \mathrm{Ma}$ and $484.9 \pm 8.7 \mathrm{Ma}$, respectively. (e) Grain CW15-014A64 which produced a ${ }^{206} \mathrm{~Pb} /{ }^{238} \mathrm{U}$ age of $433 \pm 13 \mathrm{Ma}$. (f) Grains CW15-014A-34 (shorter grain on the left) and CW15-014Ax-33 (longer grain on the right), which produced ${ }^{206} \mathrm{~Pb} /{ }^{238} \mathrm{U}$ ages of 334.9 $\pm 12 \mathrm{Ma}$ and $422.2 \pm 12 \mathrm{Ma}$, respectively. Note that the ages quoted here are for specific grains only and do not represent the interpreted crystallization ages of the units which are based on calculated concordia ages using a number of grains. The images are not adjusted for intensity or contrast, in order to show the variation in the strength of cathodoluminescence in the different grains. 
Fig. 4. U-Pb concordia diagrams for samples from (a) Rigwash Brook granodiorite, (b) Pembroke Lake monzogranite, (c) Canadian Brook tonalite, (d) Cheticamp River tonalite, and (e) Upper Fisset Brook quartz diorite. Sample locations are shown on Figure 2. Data used on diagrams are listed in Table 1. Abbreviations: MSWD, mean square weighted deviates

Fig. 5. U-Pb concordia diagrams for samples from (a) Lavis Brook quartz diorite, (b) MacLean Brook granodiorite, (c) Grand Falaise alkali-feldspar granite, and (d) French Mountain syenogranite. Sample locations are shown on Figure 2. Data used on diagrams are listed in Table 1. Abbreviations: MSWD, mean square weighted deviates.

Fig. 6. Plots illustrating the chemical characteristics of plutonic units in the Chéticamp belt. (a) $\mathrm{TiO}_{2}$ against $\mathrm{SiO}_{2}$. (b) $\mathrm{Al}_{2} \mathrm{O}_{3}$ against $\mathrm{SiO}_{2}$. (c) $\mathrm{Fe}_{2} \mathrm{O}_{3}$ (total) against $\mathrm{SiO}_{2}$. (d) $\mathrm{K}_{2} \mathrm{O}$ against $\mathrm{SiO}_{2}$, with low-, medium-, and high-K fields after LeMaitre (1989) and high-K and shoshonitic fields after Peccerillo and Taylor (1976). (e) CIPW normative Q/(Q+Or+Ab+An) versus An/(Or+An) classification diagram of Streckeisen and LeMaitre (1979). Also shown are compositional trends for types of plutonic suites from Whalen and Frost (2013): A, alkalic; A-C, alkali-calcic; C-A, calcalkalic; and C, calcic). CIPW normative mineralogy was calculated setting $\mathrm{Fe}_{2} \mathrm{O}_{3}$ at 0.15 of the total Fe. Abbreviation " $n$ " is the number of samples. Data are compiled in Supplementary Data Table $\mathrm{S} 2$.

Fig. 7. Plots illustrating chemical characteristics of plutonic units in the Chéticamp belt. (a) Modified alkali-lime index $\left(\mathrm{MALI}=\mathrm{Na}_{2} \mathrm{O}+\mathrm{K}_{2} \mathrm{O}-\mathrm{CaO}\right)$ vs. $\mathrm{SiO}_{2}$, with fields from Frost et al. 
(2001). (b) Fe-index $\left(\mathrm{FeO}^{\mathrm{t}} / \mathrm{FeO}^{\mathrm{t}}+\mathrm{MgO}\right)$ against $\mathrm{SiO}_{2}$ with fields after Frost et al. (2001). Ferroanmagnesian boundary has been modified as recommended by Frost and Frost (2008). (c) Tectonic setting discrimination diagram for granitoid rocks with fields from Pearce et al. (1984) and Pearce (1996); only samples with $>60 \% \mathrm{SiO}_{2}$ are plotted. (d) $\mathrm{Al} /(\mathrm{Na}+\mathrm{K})$ vs. $\mathrm{Al} /(\mathrm{Ca}+\mathrm{Na}+\mathrm{K}$ ) aluminum saturation index (ASI) diagram of Shand (1943) for granitoid samples $\left(\mathrm{SiO}_{2}>60 \%\right)$ from the Chéticamp plutonic belt. Fields for continental arc, continental collision, and post-orogenic granites are from Maniar and Piccoli (1989). The horizontal dashed line at ASI $=1.1$ corresponds to the boundary between I-type (below) and S-type (above) granites (Chappell and White 1992). (e) Modified Pearce et al (1984) Nb-Y diagram of Hildebrand and Whalen (2015). (f) Discrimination diagram for basaltic rocks and their differentiation products after Wood (1980); only samples with $<60 \% \mathrm{SiO}_{2}$ are plotted. Symbols are as in Figure 6 .

Fig. 8. Diagrams to illustrate REE compositions in plutons of the Chéticamp belt. (a-f) Chondritenormalized REE patterns; chondrite-normalizing values are from Sun and McDonough (1989). (g) Plot of total REE abundance against $\mathrm{SiO}_{2}$. (h) Plot of chondrite-normalized $\mathrm{La} / \mathrm{Lu}$ ratio against $\mathrm{SiO}_{2}$.

Fig. 9. Plots of (a) $\mathrm{Na}_{2} \mathrm{O}+\mathrm{K}_{2} \mathrm{O}$, (b) $\mathrm{Zr}$, and (c) $\mathrm{Nb}$ against $\mathrm{Ga} / \mathrm{Al}$ ratio with fields for A-type granitoid rocks and combined I- and S-type granitoid rocks after Whalen et al. (1987). Symbols are as in Figure 6; only samples with $\mathrm{SiO}_{2}>60 \%$ are included. 
Fig. 10. Plot of $\varepsilon \mathrm{Nd}$ against age $(\mathrm{Ma})$ comparing data from the plutonic units in the Chéticamp area and elsewhere in the Aspy and Bras d'Or terranes. Data from the Chéticamp area are from Table 2. Data from elsewhere in the Aspy and Bras d'Or terranes are from Barr and Hegner (1992) and Barr et al. (1998). Light grey shaded area indicates isotopic evolution of Neoproterozoic igneous samples from Avalonia estimated from Murphy (2002) and overlapping darker grey shaded area encloses the field for Neoproterozoic igneous samples in Ganderia estimated from Samson et al. (2000).

Fig. 11. Summary diagram comparing the plutonic history of the Cheticamp belt as determined in this study to the magmatic history of the Aspy and Bras d'Or terranes, and Ganderia in southern New Brunswick and Newfoundland. Data are compiled mainly from Barr et al. (2014a), Johnson et al. 2011, Lin et al. (2007), McLeod et al. (2003), Rogers et al. (2006), van Staal et al. 1996, White et al. (2016a), Zagorevski et al. (2007, 2010), and references therein. 


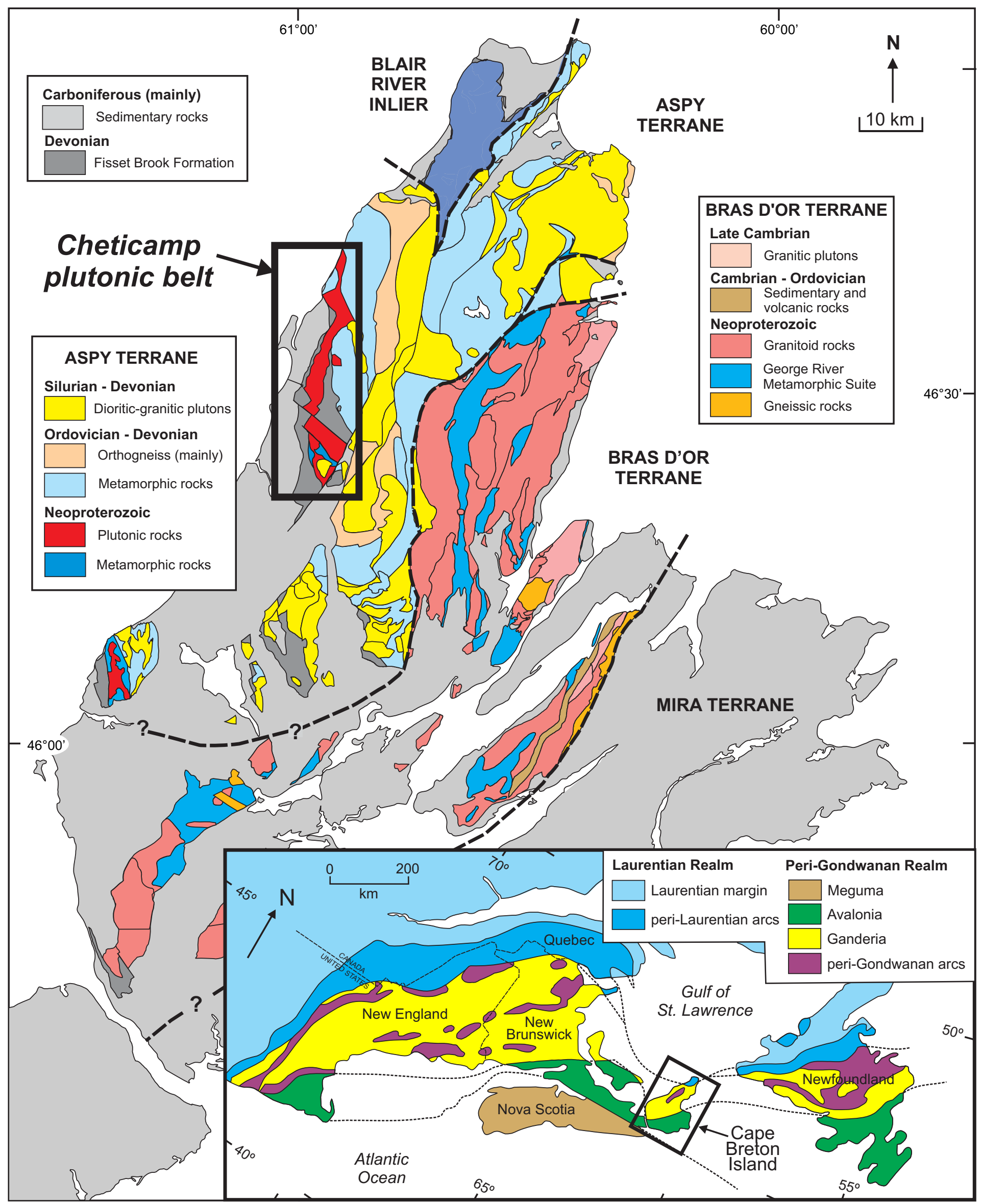




\section{LEGEND}

\section{CARBONIFEROUS}

16 HORTON, WINDSOR, MABOU,

CUMBERLAND and PICTOU GROUPS

\section{DEVONIAN}

\begin{tabular}{|c|}
\hline 15 \\
\hline 14 \\
\hline 13 \\
\hline 12 \\
\hline
\end{tabular}

FISSET BROOK FORMATION

SALMON POOL GRANITE

MARGAREE PLUTON

\section{SILURIAN}

FRENCH MOUNTAIN SYENOGRANITE

\begin{tabular}{|c|}
\hline 11 \\
\hline 10 \\
\hline 9 \\
\hline
\end{tabular}

GRAND FALAISE ALKALI-FELDSPAR GRANITE MACLEAN BROOK GRANODIORITE

LAVIS BROOK QUARTZ DIORITE

\section{CAMBRIAN to ORDOVICIAN}

\begin{tabular}{|c|}
\hline 8 \\
\hline 7 \\
\hline 6 \\
\hline
\end{tabular}

UPPER FISSET BROOK QUARTZ DIORITE CHETICAMP RIVER TONALITE

CANADIAN BROOK TONALITE

\section{CAMBRIAN}

JUMPING BROOK METAMORPHIC SUITE

5 metasedimentary, metavolcanic and metaplutonic rocks

\section{NEOPROTEROZOIC}

\begin{tabular}{|c|c}
\hline 4 & \multirow{2}{*}{ PEMBROKE LAKE MONZOGRANITE } \\
\cline { 1 - 1 } & FARM BROOK GRANODIORITE \\
\hline 2 & RIGWASH BROOK GRANODIORITE \\
\hline
\end{tabular}

GEORGE RIVER METAMORPHIC SUITE

1 STEWART BROOK FORMATION

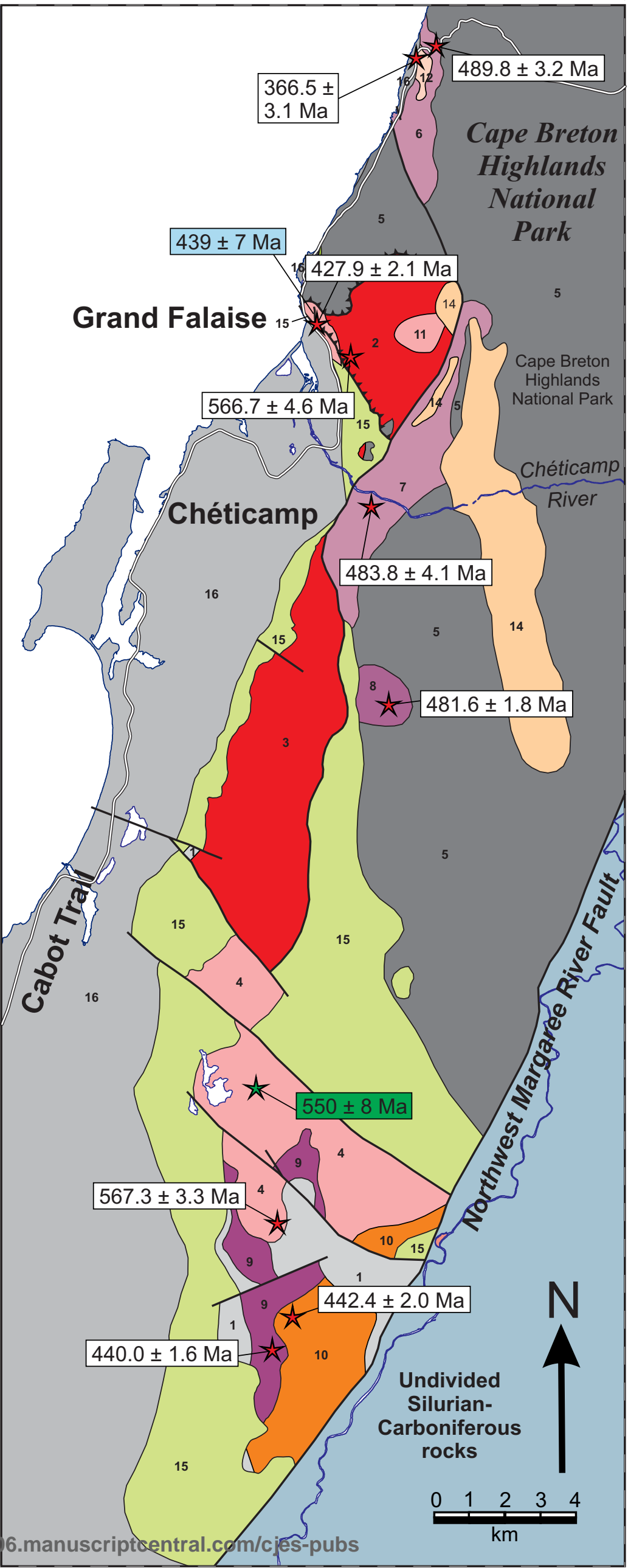




\section{Page 47 of 59}

Canadian Journal of Earth Sciences
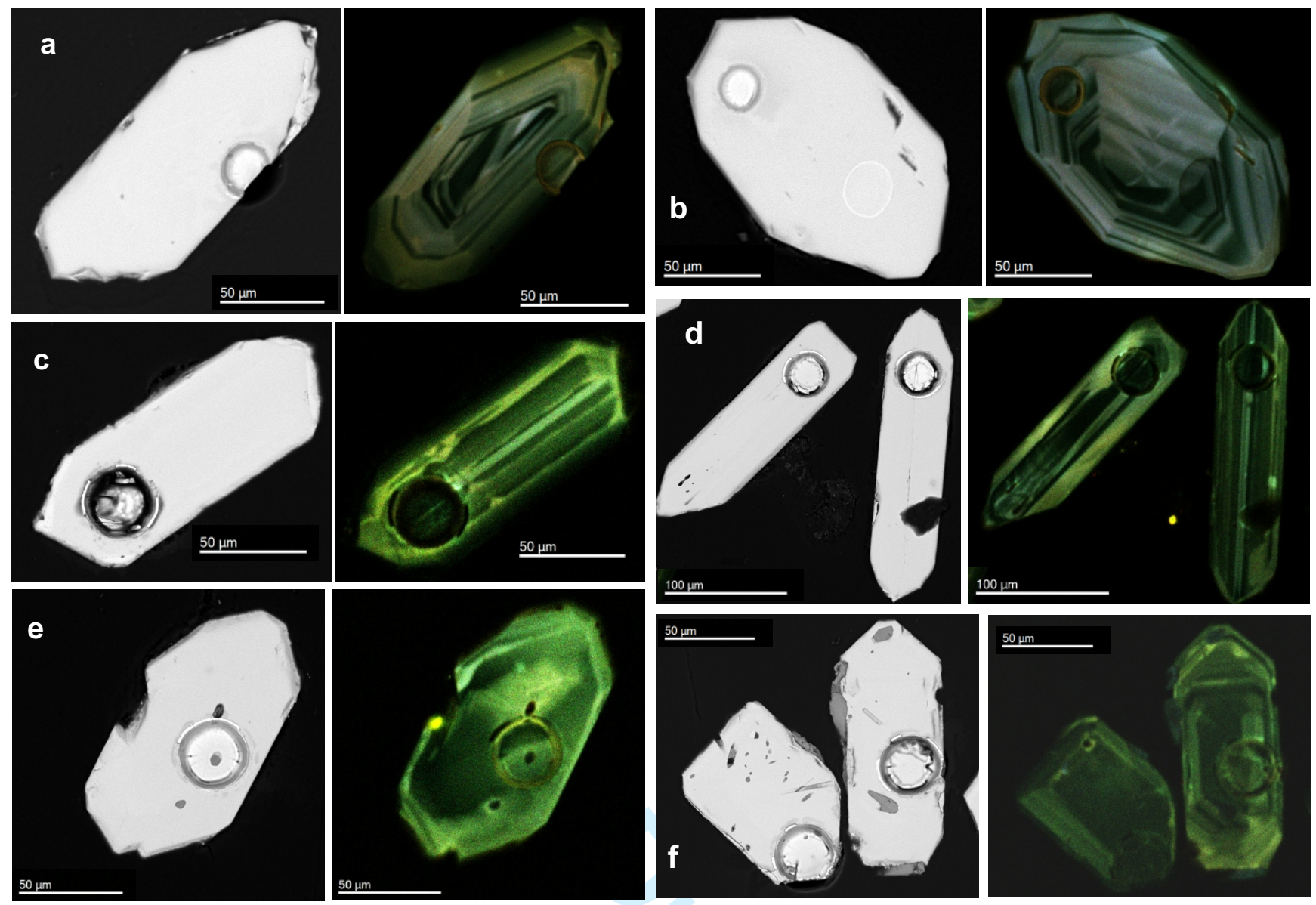

Figure 3 Slaman et al. 

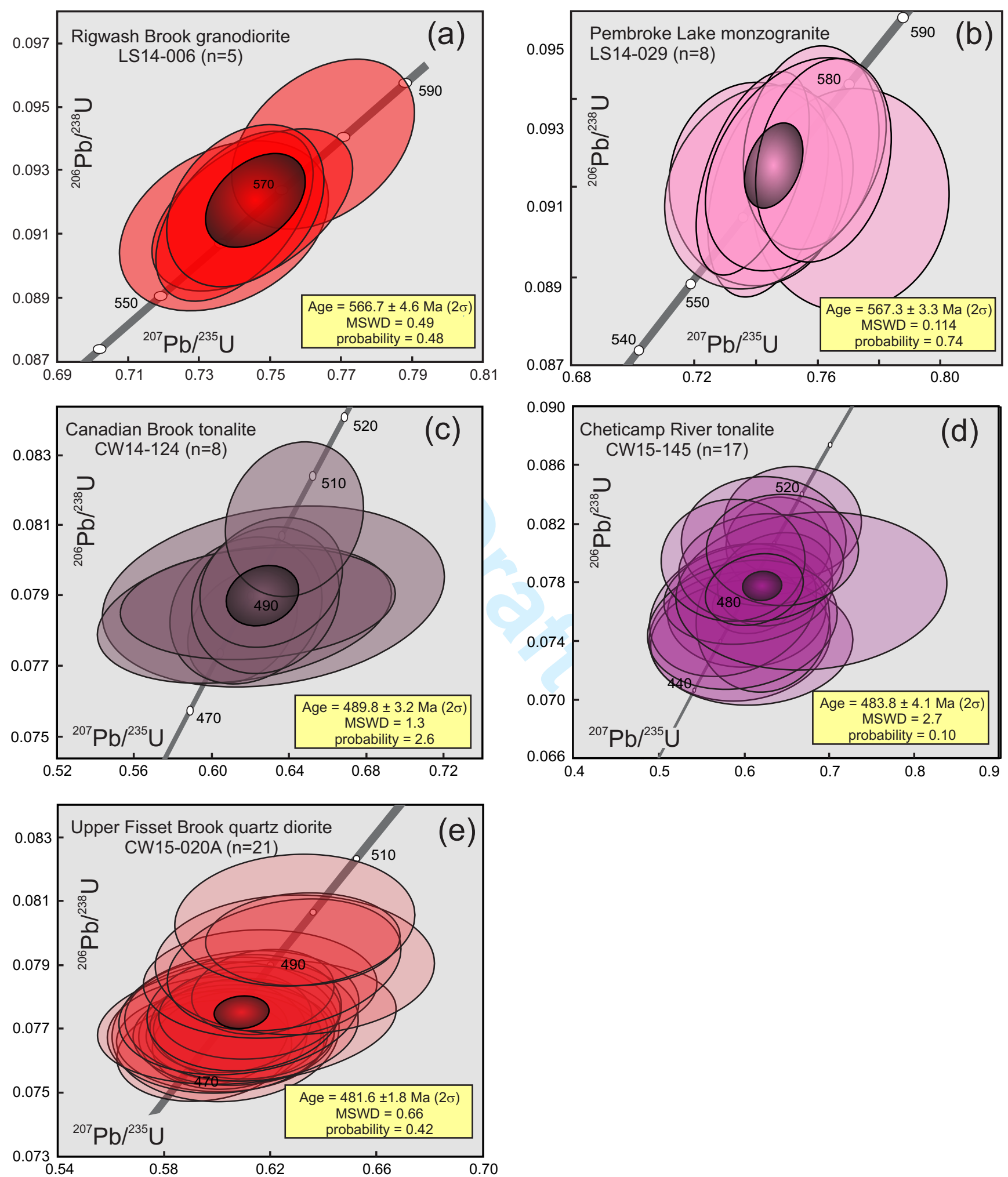

Fig. 4

Slaman et al. 

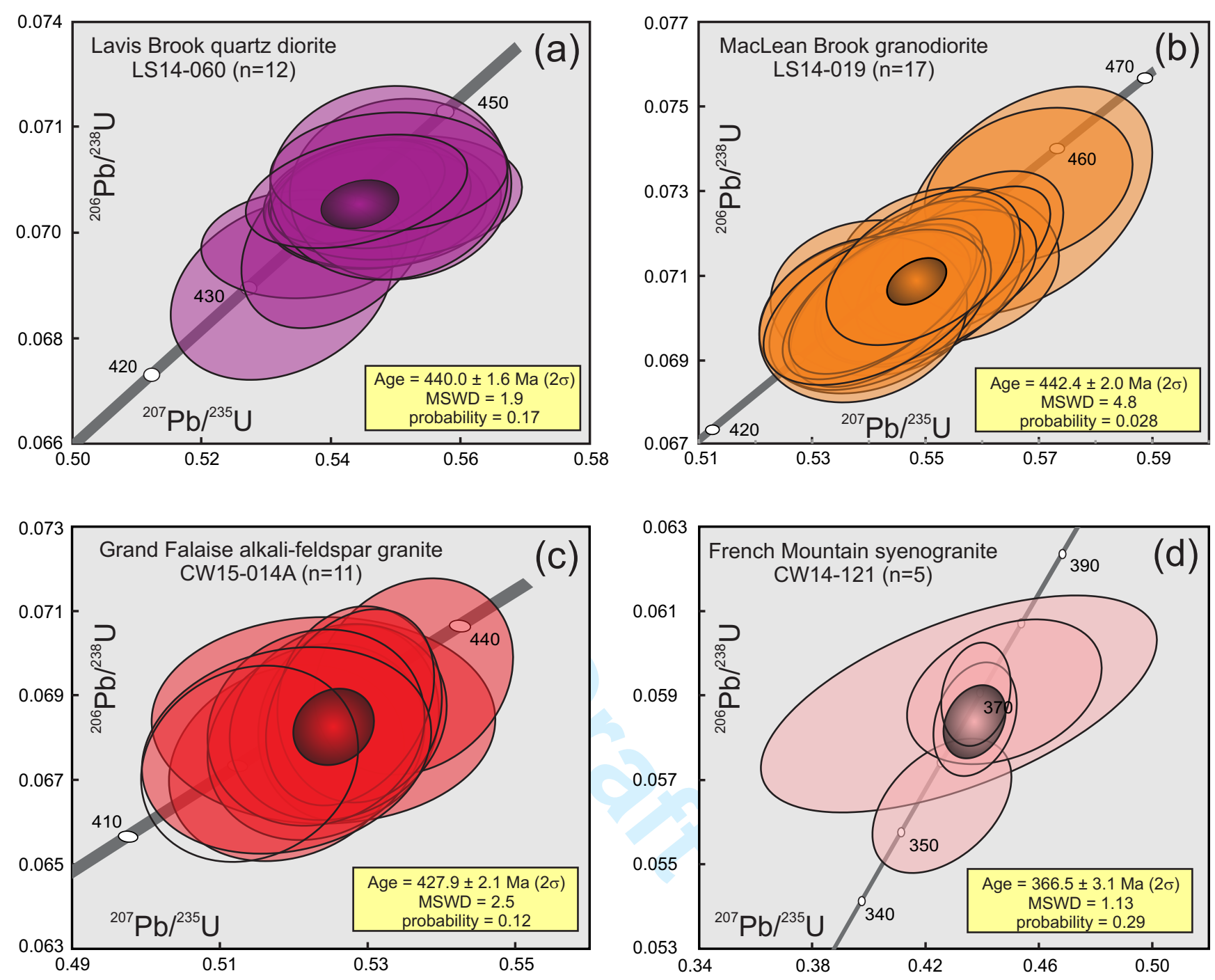

Fig. 5

Slaman et al. 

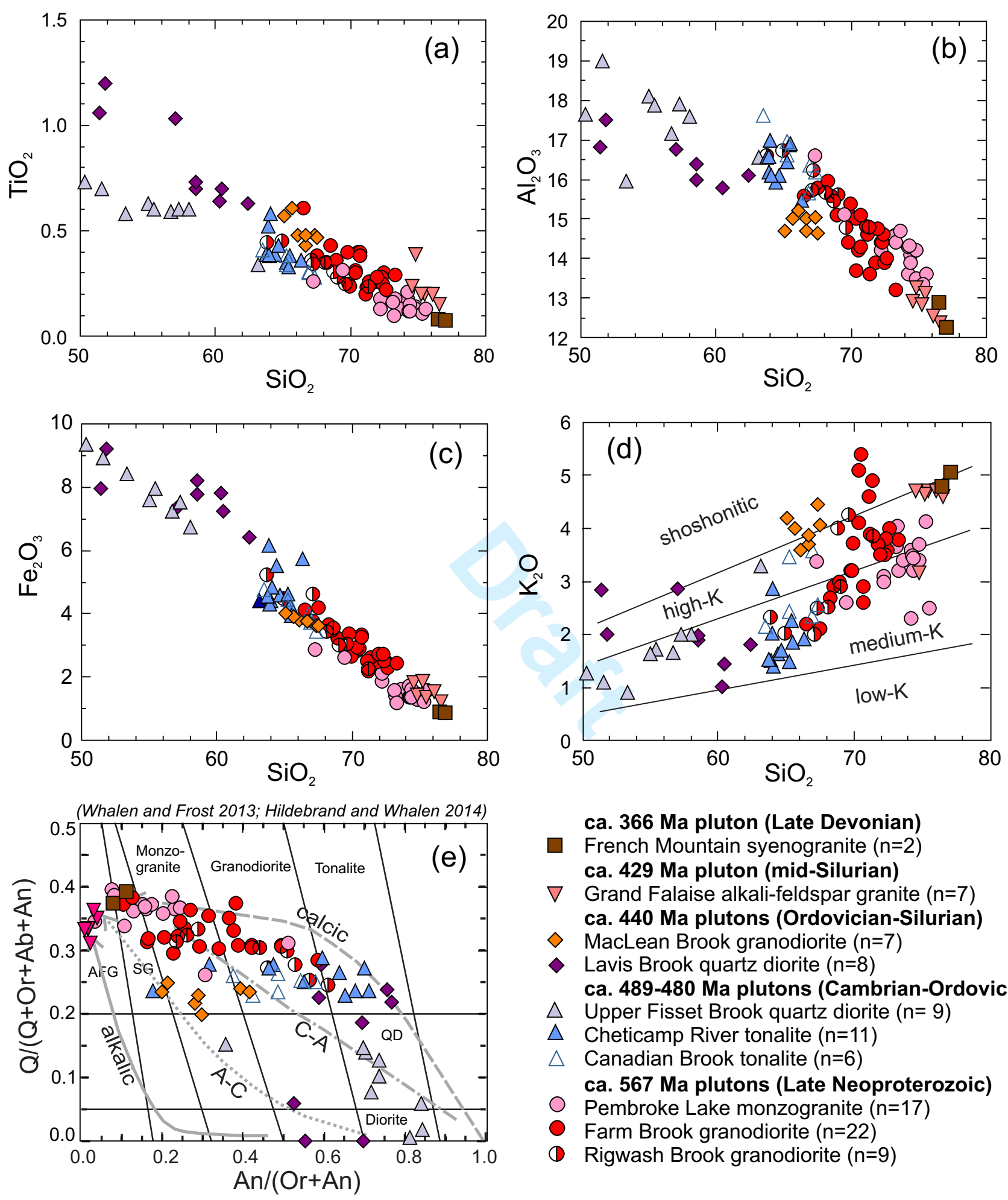
ca. 366 Ma pluton (Late Devonian)
French Mountain syenogranite $(n=2)$
ca. 429 Ma pluton (mid-Silurian)
$\nabla \quad$ Grand Falaise alkali-feldspar granite $(n=7)$
ca. $\mathbf{4 4 0}$ Ma plutons (Ordovician-Silurian)
$\diamond$ MacLean Brook granodiorite $(n=7)$
$\diamond$ Lavis Brook quartz diorite $(n=8)$
ca. 489-480 Ma plutons (Cambrian-Ordovician)
$\triangle$ Upper Fisset Brook quartz diorite $(n=9)$
$\triangle$ Cheticamp River tonalite $(n=11)$
$\triangle$ Canadian Brook tonalite $(n=6)$
ca. 567 Ma plutons (Late Neoproterozoic)
O Pembroke Lake monzogranite $(n=17)$
- Farm Brook granodiorite $(n=22)$
(1) Rigwash Brook granodiorite $(n=9)$

Figure 6 Slaman et al. 

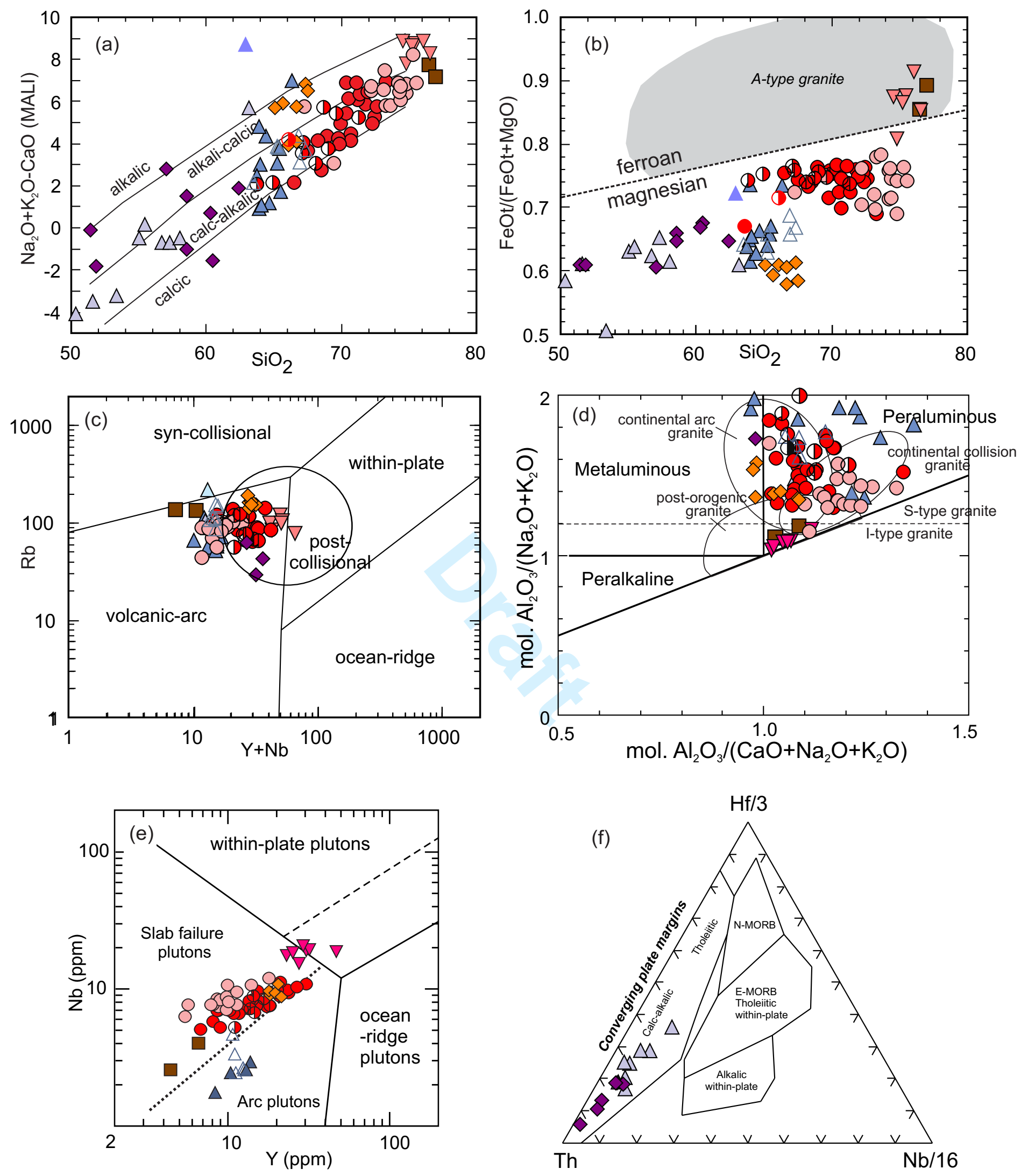

Figure 7 Slaman et al. 

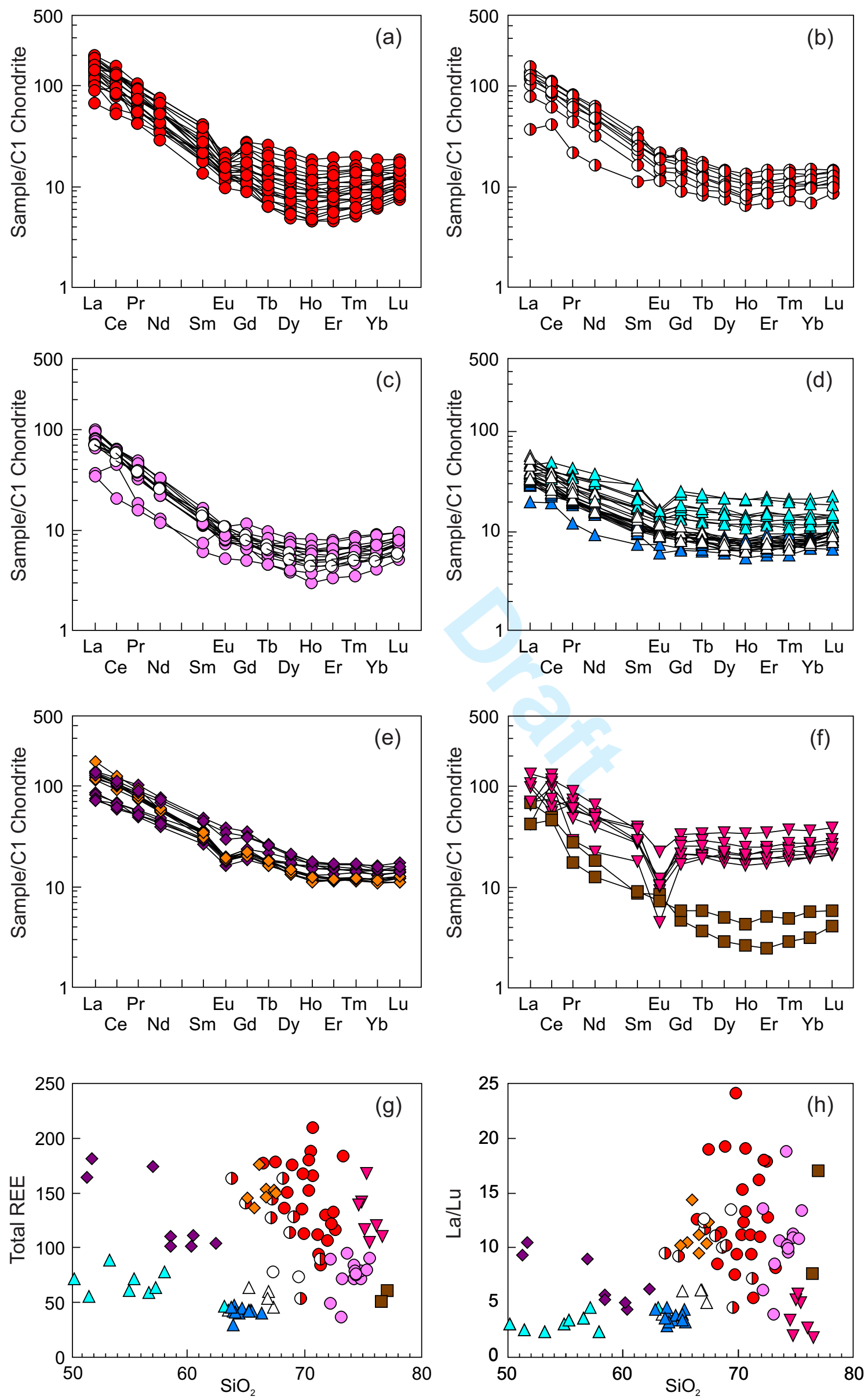

Fig. 8

https://mc06.manuscriptcentral.com/cjes-pubs Slaman et al. 

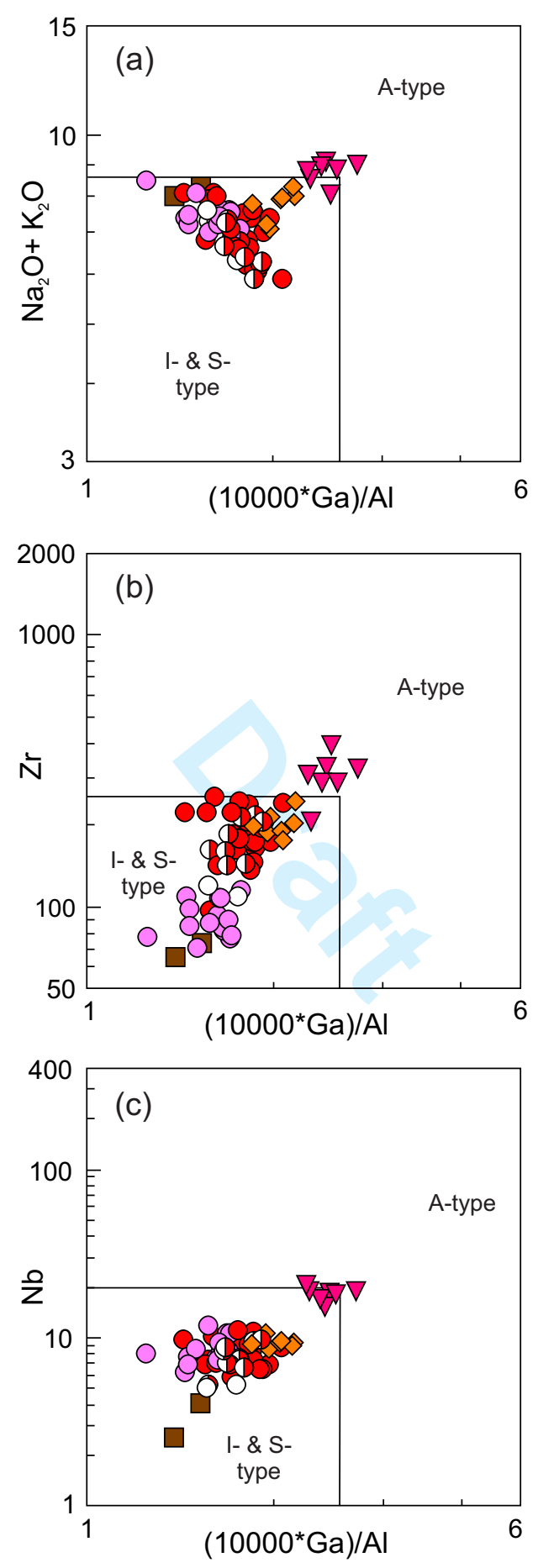

Fig. 9

Slaman et al. 


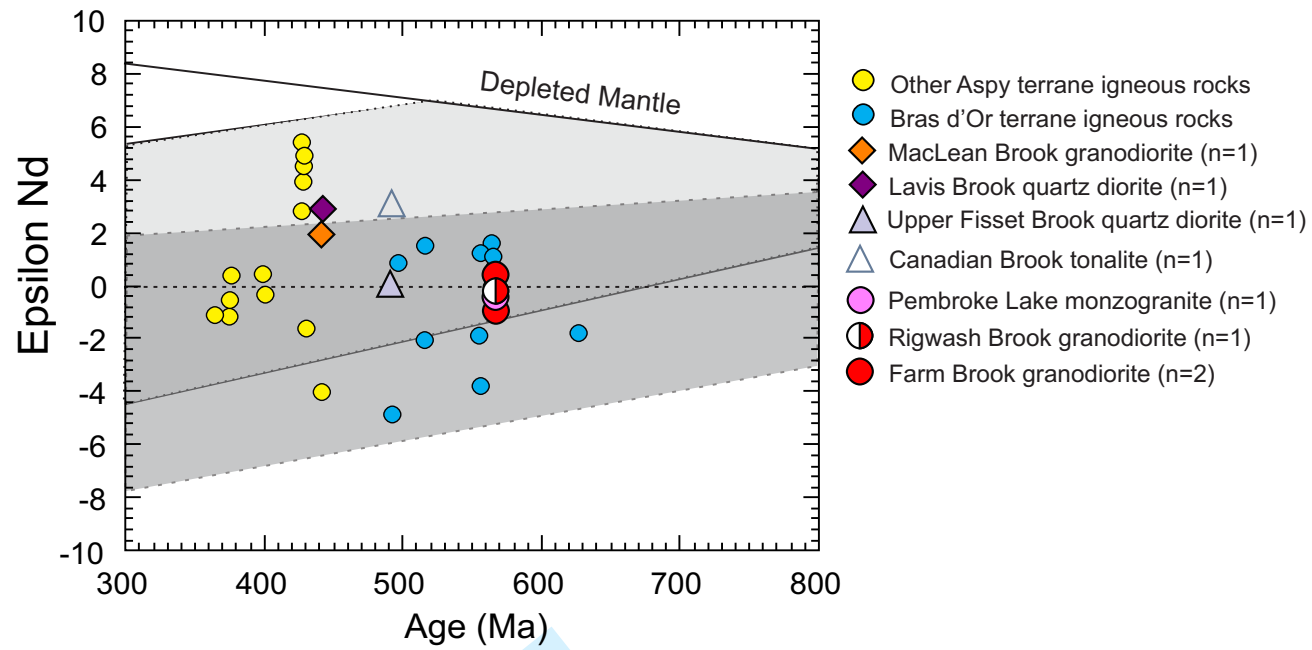

Fig. 10

Slaman et al. 


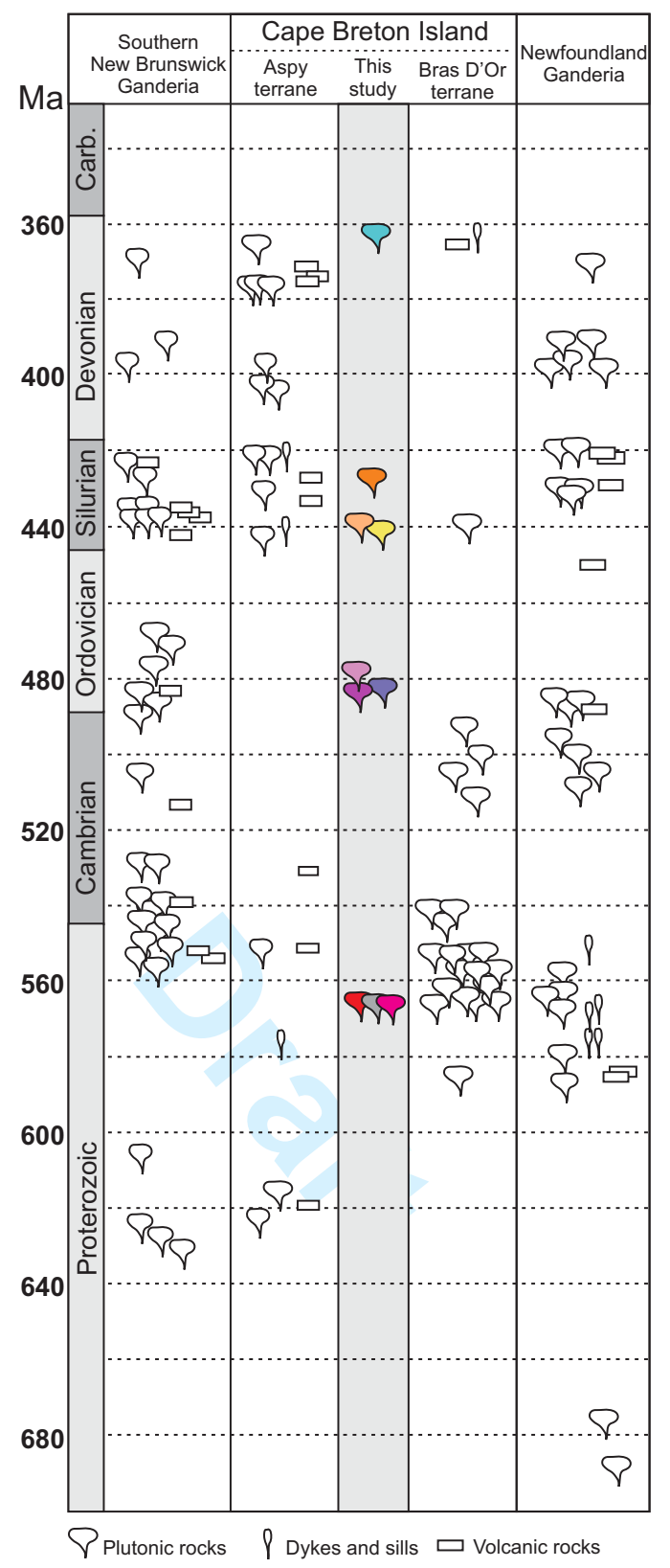

French Mountain syenogranite $(366.5 \pm 3.1 \mathrm{Ma})$
Grand Falaise K-feldspar granite $(427.9 \pm 2.1 \mathrm{Ma})$
Lavis Brook quartz diorite $(440.0 \pm 1.6 \mathrm{Ma})$
MacLean Brook granodiorite $(442.4 \pm 2.0 \mathrm{Ma})$
Upper Fisset Brook quartz diorite $(481.6 \pm 1.8 \mathrm{Ma})$
Cheticamp River tonalite (484.8 $\pm 3.9 \mathrm{Ma})$
Canadian Brook tonalite $(489.8 \pm 3.2 \mathrm{Ma})$
Rigwash Brook granodiorite $(566.0 \pm 4.9 \mathrm{Ma})$
Pembroke Lake monzogranite $(567.3 \pm 3.3 \mathrm{Ma})$
Farm Brook granodiorite (undated; age inferred)

Fig. 11

Slaman et al. 


\begin{tabular}{|c|c|c|c|c|c|c|c|c|c|c|c|c|c|c|c|c|c|c|c|c|c|c|c|}
\hline \multirow[b]{2}{*}{ Sample } & \multirow[b]{2}{*}{$\begin{array}{c}\mathrm{Pb} \\
(\mathrm{ppm})\end{array}$} & \multirow[b]{2}{*}{$\begin{array}{c}\mathrm{U} \\
(\mathrm{ppm})\end{array}$} & \multirow[b]{2}{*}{$\begin{array}{c}\text { Th } \\
(\mathrm{ppm})\end{array}$} & \multirow[b]{2}{*}{$\begin{array}{c}\mathrm{Th} / \\
\mathrm{U}\end{array}$} & \multirow[b]{2}{*}{$\begin{array}{l}{ }^{204} \mathrm{~Pb} \\
\text { (cps) }\end{array}$} & \multirow[b]{2}{*}{$2 \sigma$} & \multirow[b]{2}{*}{$\begin{array}{l}{ }^{1} \text { Filter } \\
\text { ratio }\end{array}$} & \multirow[b]{2}{*}{$\% \mathrm{~Pb}^{*}$} & \multirow[b]{2}{*}{$\begin{array}{c}{ }^{2} \mathrm{~Pb}- \\
\mathrm{C}\end{array}$} & \multicolumn{7}{|c|}{ Isotopic ratios } & \multicolumn{6}{|c|}{ Calculated ages } & \multirow[b]{2}{*}{$\begin{array}{c}\% \\
\text { conc }\end{array}$} \\
\hline & & & & & & & & & & $\begin{array}{c}{ }^{207} \mathrm{~Pb} / \\
{ }^{235} \mathrm{U}\end{array}$ & $2 \sigma$ & $\begin{array}{c}{ }^{206} \mathrm{~Pb} / \\
{ }^{238} \mathrm{U}\end{array}$ & $2 \sigma$ & $\rho$ & $\begin{array}{c}{ }^{207} \mathrm{~Pb} / \\
{ }^{206} \mathrm{~Pb} \\
\text { (uncorr) }\end{array}$ & $2 \sigma$ & $\begin{array}{c}{ }^{207} \mathrm{~Pb} /{ }^{2} \\
{ }^{06} \mathrm{~Pb} \\
\text { (calc) } \\
\end{array}$ & $2 \sigma$ & $\begin{array}{c}{ }^{207} \mathrm{~Pb} / \\
{ }^{235} \mathrm{U}\end{array}$ & $2 \sigma$ & $\begin{array}{c}{ }^{206} \mathrm{~Pb} /{ }^{2} \\
{ }^{38} \mathrm{U}\end{array}$ & $2 \sigma$ & \\
\hline \multicolumn{24}{|c|}{ LS14-006 Rigwash Brook granodiorite (UTM: 657302E, 5170285N; NAD83, Grid Zone 20T) } \\
\hline LS14-006L-1Core-1 & 50.5 & 121.9 & 123.5 & 1.01 & 1 & 16 & 1600 & 99.77 & 1 & 0.745 & 0.023 & 0.0918 & 0.0021 & 0.51227 & 0.05890 & 0.00160 & 563.4 & 59.2 & 564.0 & 13.0 & 566.0 & 13 & 100.4 \\
\hline LS14-006L-35Core-1 & 54.1 & 116.9 & 112.8 & 0.96 & -12 & 10 & -83 & 99.80 & 1 & 0.765 & 0.021 & 0.0939 & 0.0022 & 0.37254 & 0.05850 & 0.00130 & 548.5 & 48.5 & 576.4 & 12.0 & 578.6 & 13 & 100.4 \\
\hline LS14-006L-7Core-1 & 112.6 & 277.2 & 191.6 & 0.69 & 10 & 15 & 150 & 99.93 & 1 & 0.740 & 0.018 & 0.0916 & 0.0022 & 0.50839 & 0.05800 & 0.00099 & 529.8 & 37.4 & 562.9 & 11.0 & 565.2 & 13 & 100.4 \\
\hline LS14-006L-22Core-1 & 36.9 & 85.1 & 67.4 & 0.79 & 7 & 11 & 157 & 99.87 & 1 & 0.737 & 0.024 & 0.0913 & 0.0022 & 0.32403 & 0.05840 & 0.00170 & 544.8 & 63.6 & 560.0 & 14.0 & 563.4 & 13 & 100.6 \\
\hline LS14-006L-21Core-1 & 117.1 & 262.0 & 270.0 & 1.03 & 13 & 13 & 100 & 99.97 & 1 & 0.743 & 0.018 & 0.0919 & 0.0021 & 0.30753 & 0.05927 & 0.00100 & 577.0 & 36.7 & 563.3 & 10.0 & 567.0 & 12 & 100.7 \\
\hline \multicolumn{24}{|c|}{ LS14-029 Pembroke Lake monzogranite (UTM: 655332E, 5147589N; NAD83, Grid Zone 20T) } \\
\hline LS14-029L-1Core-1 & 21.5 & 49.0 & 37.4 & 0.76 & 5 & 14 & 280 & 99.48 & 1 & 0.771 & 0.026 & 0.0912 & 0.0023 & 0.05224 & 0.06150 & 0.00210 & 656.8 & 73.2 & 579.0 & 15.0 & 562.5 & 13 & 97.2 \\
\hline LS14-029L-16Core-1 & 222.5 & 529.0 & 230.9 & 0.44 & -34 & 20 & -59 & 99.89 & 1 & 0.744 & 0.016 & 0.0914 & 0.0022 & 0.37730 & 0.05920 & 0.00075 & 574.5 & 27.5 & 564.3 & 9.3 & 564.1 & 13 & 100.0 \\
\hline LS14-029L-5 & 34.1 & 79.5 & 52.4 & 0.66 & 4.4 & 9.8 & 223 & 99.85 & 1 & 0.741 & 0.025 & 0.0915 & 0.0021 & 0.19152 & 0.05770 & 0.00170 & 518.4 & 64.7 & 563.0 & 14.0 & 564.5 & 13 & 100.3 \\
\hline LS14-029L-11 & 39.7 & 99.9 & 56.4 & 0.56 & -7 & 14 & -200 & 99.75 & 1 & 0.740 & 0.023 & 0.0916 & 0.0021 & 0.01138 & 0.05860 & 0.00170 & 552.3 & 63.3 & 560.0 & 13.0 & 565.1 & 12 & 100.9 \\
\hline LS14-029L-13 & 152.5 & 372.0 & 165.4 & 0.44 & 3 & 13 & & 99.91 & 1 & 0.739 & 0.015 & 0.0919 & 0.0021 & 0.51702 & 0.05891 & 0.00087 & 563.8 & 32.2 & 561.6 & 8.9 & 566.5 & 12 & 100.9 \\
\hline LS14-029L-10 & 3.4 & 77.8 & 71.4 & 0.92 & 10 & 13 & 130 & 99.75 & 1 & 0.753 & 0.024 & 0.0921 & 0.0022 & 0.35946 & 0.05870 & 0.00170 & 556.0 & 63.2 & 570.0 & 14.0 & 568.0 & 13 & 99.6 \\
\hline LS14-029L-16 & 58.5 & 143.9 & 101.6 & 0.71 & -2 & 14 & -700 & 99.75 & 1 & 0.762 & 0.018 & 0.0922 & 0.0021 & 0.21728 & 0.05990 & 0.00120 & 600.0 & 43.4 & 575.0 & 11.0 & 568.5 & 13 & 98.9 \\
\hline LS14-029L-14b-1 & 131.0 & 295.0 & 200.4 & 0.68 & 10 & 10 & 100 & 99.84 & 1 & 0.758 & 0.018 & 0.0925 & 0.0021 & 0.15940 & 0.05970 & 0.00110 & 592.7 & 39.9 & 572.8 & 10.0 & 570.4 & 12 & 99.6 \\
\hline \multicolumn{24}{|c|}{ CW14-124 Canadian Brook tonalite (UTM: 659503E, 5178548N; NAD83, Grid Zone 20T) } \\
\hline CW14-124L-25Core-1 & 21.0 & 57.5 & 50.3 & 0.87 & -15 & 14 & -93 & 99.69 & 1 & 0.616 & 0.023 & 0.0781 & 0.0013 & 0.28283 & 0.05680 & 0.00190 & 483.8 & 73.9 & 485.0 & 14.0 & 484.4 & 7.7 & 99.9 \\
\hline CW14-124-S-37 & 17.4 & 46.4 & .0 & 0.86 & 2 & 13 & & .72 & 1 & 0.617 & 0.062 & 0.0784 & 0.0016 & 0.29760 & 0.05770 & 0.00260 & 518.4 & 98.9 & 487.0 & 38.0 & 486.4 & 9.5 & 99.9 \\
\hline CW14-124L-43 & 9.2 & 26.1 & 4.3 & 0.55 & 2 & 12 & 00 & 99.85 & 1 & 0.618 & 0.032 & 0.0785 & 0.0017 & 0.16373 & 0.05750 & 0.00290 & 510.8 & 110.9 & 490.0 & 20.0 & 487.2 & 10 & 99.4 \\
\hline CW14-124-S-2 & 43.0 & 118.5 & 99.8 & 0.84 & 8 & 16 & 200 & 99.92 & 1 & 0.624 & 0.058 & 0.0787 & 0.0013 & 0.17425 & 0.05660 & 0.00170 & 476.0 & 66.4 & 490.0 & 36.0 & 488.1 & 7.8 & 99.6 \\
\hline CW14-124L-1 & & 27. & 20.6 & 0.76 & -9 & 11 & -122 & 99.74 & 1 & 0.628 & 0.031 & 0.0788 & 0.0017 & 0.13731 & 0.05770 & 0.00270 & 518.4 & 102.7 & 496.0 & 19.0 & 488.9 & 10 & 98.6 \\
\hline CW14-124-S-7Core-1 & 6.0 & 17.5 & 8.8 & 0.50 & -10 & 11 & -110 & 99.68 & 1 & 0.632 & 0.072 & 0.0789 & 0.0021 & 0.21787 & 0.06000 & 0.00440 & 603.6 & 158.7 & 489.0 & 45.0 & 489.0 & 13 & 100.0 \\
\hline CW14-124L-34Core-1 & 16.0 & 44. & 39.0 & 0.87 & 1 & 13 & 1300 & 99.60 & 1 & 0.631 & 0.030 & 0.0793 & 0.0015 & 0.20858 & 0.05900 & 0.00260 & 567.1 & 95.9 & 496.0 & 18.0 & 491.6 & 8.9 & 99.1 \\
\hline CW14-124L-41Core-1 & 9.0 & 24.7 & 14.8 & 0.60 & 2 & 15 & 750 & 99.79 & 1 & 0.643 & 0.029 & 0.0811 & 0.0018 & 0.15205 & 0.05700 & 0.00260 & 491.5 & 100.6 & 504.0 & 18.0 & 502.6 & 11 & 99.7 \\
\hline \multicolumn{24}{|c|}{ CW15-145 Cheticamp River tonalite (657946E, 5166573N; Grid Zone 20T) } \\
\hline CW15-145S-35 & 11.0 & 33.2 & 30.6 & 0.92 & -9.6 & 9.4 & -98 & 86.39 & 1 & 0.641 & 0.050 & 0.0805 & 0.0027 & 0.01551 & 0.05970 & 0.00510 & 580.0 & 180.0 & 503.0 & 32.0 & 498.0 & 16 & 99.01 \\
\hline CW15-145L-6-1 & 11.0 & 41.3 & 27.3 & 0.66 & -12 & 13 & -108 & 73.59 & 1 & 0.596 & 0.087 & 0.0743 & 0.0036 & 0.07276 & 0.05990 & 0.00890 & 390.0 & 260.0 & 465.0 & 51.0 & 461.0 & 21 & 99.14 \\
\hline CW15-145L-5core-1 & 16.2 & 43. & 40.2 & 0.92 & -1 & 11 & -1100 & 99.38 & 1 & 0.604 & 0.076 & 0.0760 & 0.0031 & 0.03991 & 0.05630 & 0.00760 & 410.0 & 230.0 & 479.0 & 45.0 & 475.0 & 18 & 99.16 \\
\hline CW15-145S-12 & 29.2 & 89.4 & 57.4 & 0.64 & -12 & 13 & -108 & 94.86 & 1 & 0.614 & 0.041 & 0.0767 & 0.0018 & 0.19025 & 0.05730 & 0.00360 & 440.0 & 130.0 & 480.0 & 26.0 & 476.0 & 11 & 99.17 \\
\hline & & & & 0.71 & -17.5 & 9.5 & & & 1 & 0.658 & 0.066 & 0.0821 & 0.0031 & 0.00939 & 0.05990 & 0.00660 & 500.0 & 210.0 & 515.0 & 43.0 & 511.0 & 19 & 99.22 \\
\hline CW15-145L-9_1 & 9.2 & 33.6 & 31.6 & 0.94 & -6 & 11 & -183 & 70.62 & 1 & 0.610 & 0.097 & 0.0739 & 0.0035 & 0.04426 & 0.06000 & 0.00900 & 390.0 & 270.0 & 462.0 & 57.0 & 459.0 & 21 & 99.35 \\
\hline CW15-145L-2 -1 & 17.5 & 45.6 & 37.5 & 0.82 & 1 & 13 & 1300 & 96.58 & 1 & 0.623 & 0.064 & 0.0754 & 0.0040 & 0.03917 & 0.05750 & 0.00660 & 440.0 & 210.0 & 475.0 & 41.0 & 472.0 & 24 & 99.37 \\
\hline CW15-145L-21 core -1 & 14.2 & 33.0 & 27.6 & 0.84 & 11.3 & 9.5 & 84 & 83.10 & 1 & 0.588 & 0.080 & 0.0761 & 0.0037 & 0.22840 & 0.05510 & 0.00750 & 300.0 & 230.0 & 475.0 & 49.0 & 472.0 & 22 & 99.37 \\
\hline CW15-145L-21rim-1 & 13.6 & 45.4 & 37.2 & 0.82 & -7.6 & 8.6 & -113 & 76.52 & 1 & 0.606 & 0.081 & 0.0772 & 0.0028 & 0.18462 & 0.05740 & 0.00770 & 350.0 & 250.0 & 482.0 & 51.0 & 479.0 & 17 & 99.38 \\
\hline & 11.0 & 36.3 & 25.0 & 0.69 & -14 & 11 & -79 & 80.99 & 1 & 0.637 & 0.055 & 0.0782 & 0.0026 & 0.18391 & 0.05980 & 0.00530 & 490.0 & 180.0 & 488.0 & 34.0 & 485.0 & 16 & 99.39 \\
\hline CW15-145L-2_1 & 14.9 & 33.2 & 33.4 & 1.01 & 4 & 11 & 275 & 88.57 & 1 & 0.624 & 0.079 & 0.0808 & 0.0036 & 0.00847 & 0.06300 & 0.00870 & 520.0 & 250.0 & 503.0 & 52.0 & 500.0 & 21 & 99.4 \\
\hline CW15-145L-3_1 & 9.8 & 30.6 & 28.7 & 0.94 & -6 & 12 & -200 & 86.79 & 1 & 0.599 & 0.091 & 0.0751 & 0.0036 & 0.17740 & 0.05320 & 0.00880 & 280.0 & 280.0 & 468.0 & 58.0 & 466.0 & 22 & 99.57 \\
\hline CW15-145L-1_1 & 4.4 & 18.9 & 9.9 & 0.52 & -7 & 15 & -214 & 42.53 & 1 & 0.680 & 0.130 & 0.0774 & 0.0044 & 0.09819 & 0.05900 & 0.01200 & 410.0 & 350.0 & 480.0 & 83.0 & 479.0 & 26 & 99.79 \\
\hline CW15-145S-34 & 8.6 & 25.9 & 17.9 & 0.69 & -6 & 12 & -200 & 91.90 & 1 & 0.621 & 0.079 & 0.0790 & 0.0030 & 0.09520 & 0.05650 & 0.00740 & 400.0 & 230.0 & 491.0 & 49.0 & 490.0 & 18 & 99.8 \\
\hline
\end{tabular}

https://mc06.manuscriptcentral.com/cjes-pubs 
CW15-145L-14 CW15-145L-19-1 CW15-145S-32
$15.2 \quad 45.2$

$19.9 \quad 50.9$ $22.9 \quad 61.5$ $\begin{array}{lllll}29.5 & 0.65 & -5.4 & 9.9 & -183\end{array}$ $\begin{array}{lllll}40.5 & 0.80 & -1 & 9.6 & -960\end{array}$ 59.90 .97
$92.09 \quad 1$ $\begin{array}{lllllll}0.613 & 0.047 & 0.0775 & 0.0020 & 0.21245 & 0.05600 & 0.00430\end{array}$

\section{CW15-020A Upper Fisset Brook quartz diorite (UTM: 658254E, 5161280N; NAD83, Grid Zone 20T)}

CEW15-020B-38

CEW15-020B-44

CEW15-020B-5

CEW15-020B-23

CEW15-020B-4

CEW15-020B-10

CEW15-020B-22

CEW15-020B-47

CEW15-020B-2

CEW15-020B-35

CEW15-020B-50

CEW15-020B-20

CEW15-020B-51

CEW15-020B-14

CEW15-020B-26

CEW15-020B-11

CEW15-020B-1

CEW15-020B-59

CEW15-020B-30

CEW15-020B-12

CEW15-020B-21

$\begin{array}{rrrr}30.1 & 79.8 & 101.6 & 1.27 \\ 20.5 & 55.9 & 56.0 & 1.00 \\ 41.7 & 108.4 & 170.8 & 1.58 \\ 26.6 & 70.8 & 88.8 & 1.25 \\ 31.4 & 82.1 & 114.1 & 1.39 \\ 31.1 & 76.4 & 107.3 & 1.40 \\ 21.3 & 59.7 & 52.1 & 0.87 \\ 21.8 & 62.4 & 51.1 & 0.82 \\ 29.3 & 78.3 & 102.4 & 1.31 \\ 39.0 & 97.8 & 161.6 & 1.65 \\ 45.5 & 106.7 & 191.0 & 1.79 \\ 15.2 & 43.1 & 29.5 & 0.68 \\ 20.3 & 56.8 & 53.1 & 0.94 \\ 40.5 & 104.4 & 161.4 & 1.55 \\ 27.1 & 72.7 & 76.3 & 1.05 \\ 38.4 & 98.2 & 148.7 & 1.51 \\ 20.9 & 55.4 & 57.8 & 1.04 \\ 28.4 & 76.8 & 71.6 & 0.93 \\ 22.0 & 58.9 & 67.6 & 1.15 \\ 24.9 & 66.3 & 64.3 & 0.97 \\ 23.5 & 59.0 & 64.9 & 1.10\end{array}$

$\begin{array}{llll}99.86 & 1 & 0.595 & 0.027\end{array}$

157

$8 \quad 15$

$-5 \quad 12$

$-2 \quad 13$

$\begin{array}{ll}-8 & 15\end{array}$

$-10 \quad 17$

1700

1300

360

280

107

156

57

200

650

121

1600

300

467 $\begin{array}{lllllllll}9 & 1 & 0.595 & 0.027 & 0.0763 & 0.0013 & 0.14090 & 0.05640 & 0.00250\end{array}$

$\begin{array}{llllllllll}9.76 & 1 & 0.601 & 0.021 & 0.0767 & 0.0012 & 0.19881 & 0.05670 & 0.00190\end{array}$

$\begin{array}{llllllllll}99.72 & 1 & 0.602 & 0.026 & 0.0768 & 0.0014 & 0.03718 & 0.05720 & 0.00260\end{array}$

$\begin{array}{llllllllll}99.58 & 1 & 0.606 & 0.027 & 0.0768 & 0.0012 & 0.02588 & 0.05680 & 0.00260\end{array}$

$\begin{array}{lllllllllll}99.53 & 1 & 0.603 & 0.035 & 0.0769 & 0.0018 & 0.06824 & 0.05820 & 0.00360\end{array}$

$\begin{array}{llllllllll}99.70 & 1 & 0.606 & 0.031 & 0.0768 & 0.0013 & 0.02891 & 0.05720 & 0.00290\end{array}$

$\begin{array}{llllllllll}99.75 & 1 & 0.600 & 0.034 & 0.0768 & 0.0015 & 0.04110 & 0.05690 & 0.00320\end{array}$

$\begin{array}{llllllllll}99.68 & 1 & 0.610 & 0.028 & 0.0770 & 0.0013 & 0.01106 & 0.05710 & 0.00270\end{array}$

$\begin{array}{llllllllll}99.80 & 1 & 0.605 & 0.025 & 0.0772 & 0.0013 & 0.11785 & 0.05720 & 0.00230\end{array}$

$\begin{array}{llllllllll}99.64 & 1 & 0.611 & 0.046 & 0.0772 & 0.0016 & 0.20730 & 0.05700 & 0.00380\end{array}$

$\begin{array}{llllllllll}99.81 & 1 & 0.609 & 0.036 & 0.0773 & 0.0016 & 0.00362 & 0.05710 & 0.00340\end{array}$

$\begin{array}{llllllllll}99.61 & 1 & 0.608 & 0.037 & 0.0775 & 0.0016 & 0.17498 & 0.05790 & 0.00350\end{array}$

$\begin{array}{llllllllll}99.54 & 1 & 0.612 & 0.028 & 0.0775 & 0.0012 & 0.07432 & 0.05810 & 0.00290\end{array}$

$\begin{array}{llllllllll}99.79 & 1 & 0.610 & 0.030 & 0.0775 & 0.0015 & 0.10478 & 0.05720 & 0.00290\end{array}$

$\begin{array}{llllllllll}99.66 & 1 & 0.617 & 0.022 & 0.0782 & 0.0011 & 0.14285 & 0.05690 & 0.00200\end{array}$

$\begin{array}{llllllllll}99.54 & 1 & 0.616 & 0.036 & 0.0784 & 0.0014 & 0.01487 & 0.05810 & 0.00350\end{array}$

$\begin{array}{llllllllll}99.69 & 1 & 0.629 & 0.043 & 0.0790 & 0.0018 & 0.02163 & 0.05810 & 0.00410\end{array}$

$\begin{array}{llllllllll}99.66 & 1 & 0.625 & 0.036 & 0.0790 & 0.0017 & 0.24010 & 0.05690 & 0.00300\end{array}$

$\begin{array}{lllllllllll}99.74 & 1 & 0.632 & 0.030 & 0.0798 & 0.0012 & 0.07174 & 0.05700 & 0.00270\end{array}$

$\begin{array}{llllllllll}99.73 & 1 & 0.629 & 0.037 & 0.0804 & 0.0017 & 0.07630 & 0.05760 & 0.00360\end{array}$ $\begin{array}{llllll}380.0 & 220.0 & 493.0 & 46.0 & 492.0 & 21\end{array}$ $\begin{array}{lllllll}420.0 & 160.0 & 481.0 & 31.0 & 481.0 & 12 & 100\end{array}$

\section{LS14-060 Lavis Brook quartz diorite (UTM: 655044E, 5142675N; NAD83, Grid Zone 20T)}

LS14-060S-4

LS14-060L-3

LS14-060S-12

LS14-060L-7

LS14-060L-9

LS14-060L-16

LS14-060L-1

LS14-060L-14

LS14-060S-8

LS14-060S-2B-1

LS14-060L-6

LS14-060L-24

$\begin{array}{llll}88.0 & 253.0 & 254.8 & 1.01\end{array}$

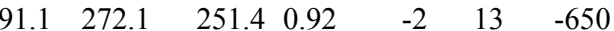

$99.87 \quad 1$

$\begin{array}{lllllll}0.532 & 0.014 & 0.0689 & 0.0014 & 0.28135 & 0.05612 & 0.00079\end{array}$ $\begin{array}{llllllllll}99.92 & 1 & 0.536 & 0.013 & 0.0698 & 0.0008 & 0.08689 & 0.05580 & 0.00110\end{array}$ $\begin{array}{llll}67.8 & 624.0 & 478.0 & 0.77\end{array}$ $\begin{array}{llll}49.4 & 148.0 & 127.5 & 0.86\end{array}$ $\begin{array}{lllll}51.1 & 155.4 & 125.0 & 0.80\end{array}$ $\begin{array}{lllll}47.3 & 140.6 & 123.5 & 0.88\end{array}$ $\begin{array}{llll}162.0 & 456.5 & 291.4 & 0.64\end{array}$ $\begin{array}{llll}178.0 & 549.0 & 386.7 & 0.70\end{array}$ $\begin{array}{llll}80.1 & 294.9 & 324.8 & 1.10\end{array}$ $\begin{array}{llll}72.8 & 211.0 & 209.4 & 0.99\end{array}$ $\begin{array}{llll}39.2 & 122.1 & 70.7 & 0.58\end{array}$ $\begin{array}{llll}50.3 & 155.1 & 121.9 & 0.79\end{array}$

$\begin{array}{lll}-5 & 12 & -240\end{array}$

$-1 \quad 11-1100$

$\begin{array}{lll}-2 & 13 & -650\end{array}$

$\begin{array}{lll}-8 & 13 & -163\end{array}$

$\begin{array}{lll}-16 & 20 & -125\end{array}$

$\begin{array}{lll}5 & 12 & 240\end{array}$

$8 \quad 13 \quad 163$

$9 \quad 13 \quad 144$

$\begin{array}{lll}-3 & 12 & -400\end{array}$

$\begin{array}{lll}6 & 14 & 233\end{array}$ $\begin{array}{llllll}444.0 & 97.0 & 476.0 & 18.0 & 473.8 & 7.9\end{array}$ $\begin{array}{lllllll}0.0 & 120.0 & 479.0 & 20.0 & 475.6 & 7.7 & 99.3\end{array}$ $\begin{array}{lllllll} & 74.0 & 479.0 & 13.0 & 476.3 & 7.2 & 99.4\end{array}$ $\begin{array}{lllllll}467.0 & 99.0 & 477.0 & 17.0 & 476.8 & 8.2 & 100.0\end{array}$ $\begin{array}{lllllll}491.0 & 99.0 & 480.0 & 18.0 & 477.0 & 7.3 & 99.4\end{array}$ $\begin{array}{lllllll}500.0 & 130.0 & 478.0 & 22.0 & 477.0 & 11 & 99.8\end{array}$ $\begin{array}{lllllll}460.0 & 110.0 & 477.0 & 19.0 & 477.0 & 8.1 & 100.0\end{array}$ $\begin{array}{llllllll}460.0 & 120.0 & 478.0 & 21.0 & 477.1 & 8.8 & 99.8\end{array}$ $\begin{array}{lllllll}490.0 & 100.0 & 481.0 & 18.0 & 477.9 & 8 & 99.4\end{array}$ $\begin{array}{llllllll}468.0 & 90.0 & 482.0 & 16.0 & 479.0 & 7.6 & 99.4\end{array}$ $\begin{array}{lllllll}480.0 & 150.0 & 481.0 & 28.0 & 479.5 & 9.4 & 99.7\end{array}$ $\begin{array}{lllllll}460.0 & 120.0 & 480.0 & 22.0 & 479.9 & 9.3 & 100.0\end{array}$ $\begin{array}{lllllll}520.0 & 120.0 & 484.0 & 22.0 & 480.9 & 9.7 & 99.4\end{array}$ $\begin{array}{lllllll}510.0 & 100.0 & 483.0 & 18.0 & 480.9 & 7.1 & 99.6\end{array}$ $\begin{array}{llllllll}450.0 & 110.0 & 483.0 & 19.0 & 480.9 & 8.7 & 99.6\end{array}$ $\begin{array}{llllllll}469.0 & 77.0 & 489.0 & 14.0 & 485.0 & 6.6 & 99.2\end{array}$ $\begin{array}{llllllll}500.0 & 120.0 & 491.0 & 22.0 & 487.5 & 8.4 & 99.3\end{array}$ $\begin{array}{lllllll}500.0 & 150.0 & 491.0 & 27.0 & 490.0 & 11 & 99.8\end{array}$ $\begin{array}{lllllll}500.0 & 110.0 & 492.0 & 22.0 & 490.2 & 9.9 & 99.6\end{array}$ $\begin{array}{lllllll}470.0 & 100.0 & 498.0 & 19.0 & 494.6 & 7.3 & 99.3\end{array}$ $\begin{array}{llllllll}510.0 & 130.0 & 501.0 & 24.0 & 498.1 & 10 & 99.4\end{array}$

\section{LS14-019 MacLean Brook granodiorite (UTM: 655458E, 5145071N; NAD83, Grid Zone 20T)}

LS14-019L-1

LS14-019L-12

LS14-019L-22

LS14-019L-19

LS14-019L-13

LS14-019L-39Core-1

$\begin{array}{llll}106.6 & 320.0 & 188.7 & 0.59\end{array}$

$\begin{array}{llll}137.3 & 415.2 & 288.1 & 0.69\end{array}$

\section{$7 \quad 13$}

186

$99.88 \quad 1$

$\begin{array}{llllllllll}99.84 & 1 & 0.547 & 0.014 & 0.0705 & 0.0009 & 0.13624 & 0.05640 & 0.00130\end{array}$

$\begin{array}{llllllllll}99.80 & 1 & 0.548 & 0.015 & 0.0706 & 0.0010 & 0.12922 & 0.05670 & 0.00140\end{array}$

$\begin{array}{llllllllll}99.73 & 1 & 0.550 & 0.016 & 0.0707 & 0.0010 & 0.16889 & 0.05660 & 0.00140\end{array}$

$\begin{array}{llllllllll}99.86 & 1 & 0.547 & 0.012 & 0.0708 & 0.0009 & 0.13836 & 0.05570 & 0.00088\end{array}$

$\begin{array}{llllllllll}99.92 & 1 & 0.544 & 0.011 & 0.0708 & 0.0008 & 0.40589 & 0.05593 & 0.00074\end{array}$

$\begin{array}{llllllllll}99.86 & 1 & 0.551 & 0.014 & 0.0708 & 0.0014 & 0.06193 & 0.05652 & 0.00086\end{array}$

$\begin{array}{llllllllll}99.75 & 1 & 0.549 & 0.015 & 0.0710 & 0.0015 & 0.05930 & 0.05640 & 0.00110\end{array}$

$\begin{array}{llllllllll}99.83 & 1 & 0.549 & 0.015 & 0.0712 & 0.0009 & 0.07794 & 0.05630 & 0.00140\end{array}$

$\begin{array}{llllllllll}99.85 & 1 & 0.544 & 0.014 & 0.0708 & 0.0009 & 0.36716 & 0.05640 & 0.00130\end{array}$

457.1

444.4

462.6

468.1

479.9

476.0

440.4

449.6

68.1

464.2

468.1 $\begin{array}{llllll}31.2 & 433.0 & 8.9 & 429.7 & 8.5 & 99.2\end{array}$ $\begin{array}{lllllll}43.8 & 435.1 & 8.6 & 434.9 & 5.1 & 100.0\end{array}$ $\begin{array}{llllll}22.8 & 438.8 & 8.0 & 435.6 & 8.4 & 99.3\end{array}$ $\begin{array}{llllll}51.0 & 442.0 & 9.5 & 439.0 & 5.6 & 99.3\end{array}$ $\begin{array}{llllll}54.6 & 442.5 & 9.8 & 439.5 & 6 & 99.3\end{array}$ $\begin{array}{lllllll}54.7 & 443.8 & 10.0 & 440.1 & 5.8 & 99.2\end{array}$ $\begin{array}{llllll}35.2 & 442.7 & 7.8 & 440.7 & 5.1 & 99.5\end{array}$ $\begin{array}{llllll}29.4 & 441.3 & 6.9 & 440.8 & 4.8 & 99.9\end{array}$ $\begin{array}{llllll}33.7 & 445.1 & 8.8 & 441.2 & 8.5 & 99.1\end{array}$ $\begin{array}{llllll}43.2 & 443.9 & 9.8 & 441.8 & 8.9 & 99.5\end{array}$ $\begin{array}{lllllll}55.1 & 443.4 & 9.8 & 443.1 & 5.6 & 99.9\end{array}$ $\begin{array}{llllll}51.0 & 441.1 & 9.3 & 441.3 & 5.3 & 100.0\end{array}$

LS14-019L-3Core-1

$\begin{array}{lllll}58.3 & 182.2 & 101.8 & 0.56\end{array}$

$\begin{array}{lllll}86.4 & 262.0 & 172.0 & 0.66\end{array}$

$\begin{array}{rr}-15 & 10 \\ 4 & 11\end{array}$

275

$99.78 \quad 1$

$0.554 \quad 0.01$

$\begin{array}{rr}4 & 11 \\ 10 & 11\end{array}$

$\begin{array}{lll}-2 & 13 & -650\end{array}$

$\begin{array}{llllllllll}99.87 & 1 & 0.557 & 0.014 & 0.0715 & 0.0016 & 0.49329 & 0.05663 & 0.00075\end{array}$

476.0

458.7

$\begin{array}{lllllllll}0.549 & 0.015 & 0.0708 & 0.0016 & 0.39307 & 0.05690 & 0.00110 & 487.7 \\ 0.568 & 0.018 & 0.0727 & 0.0022 & 0.41723 & 0.05730 & 0.00160 & 503.1\end{array}$

$\begin{array}{lllll}4 & 449.4 & 8.9 & 445.0 & 9.6\end{array}$ $\begin{array}{llllll}27.6 & 447.7 & 9.0 & 443.6 & 8.7\end{array}$ $\begin{array}{lllll}42.7 & 444.6 & 9.8 & 440.8 & 9.6\end{array}$ $\begin{array}{lllll}61.5 & 455.9 & 11.0 & 452.6 & 13\end{array}$ $\begin{array}{llll}77.6 & 236.4 & 179.5 & 0.76\end{array}$

(1)

5
.3
.0
.8
.0
.8
.4
.7
.0
.6
.6
.3
.3
4

.2
.0
99
.3
9.3
9
.5
99
.1
9.5
9.9
90.0
9.0
99
.0
9.1
9.3
9.3
9.4




\begin{tabular}{|c|c|c|c|c|c|c|c|c|c|c|c|c|c|c|c|c|c|c|c|c|c|c|c|}
\hline LS14-019L-13Core-1 & 77.5 & 229.0 & 206.0 & 0.90 & -10 & 13 & -130 & 99.73 & 1 & 0.542 & 0.016 & 0.0702 & 0.0016 & 0.44819 & 0.05730 & 0.00110 & 503.1 & 42.3 & 439.8 & 11.0 & 437.4 & 9.7 & 99.5 \\
\hline LS14-019L-37 & 124.7 & 382.3 & 262.9 & 0.69 & -5 & 11 & -220 & 99.89 & 1 & 0.542 & 0.013 & 0.0702 & 0.0015 & 0.52527 & 0.05555 & 0.00066 & 434.4 & 26.5 & 439.4 & 8.7 & 437.2 & 8.8 & 99.5 \\
\hline LS14-019L-8 & 96.2 & 294.8 & 188.6 & 0.64 & -12.8 & 9.9 & -77 & 99.72 & 1 & 0.568 & 0.015 & 0.0731 & 0.0015 & 0.26796 & 0.05680 & 0.00100 & 483.8 & 38.9 & 456.9 & 9.5 & 454.8 & 8.9 & 99.5 \\
\hline LS14-019L-15Core-1 & 75.3 & 240.0 & 197.8 & 0.82 & 9 & 14 & 156 & 99.86 & 1 & 0.539 & 0.015 & 0.0699 & 0.0016 & 0.19681 & 0.05640 & 0.00110 & 468.1 & 43.2 & 437.4 & 9.5 & 435.7 & 9.4 & 99.6 \\
\hline LS14-019L-20Core-1 & 126.4 & 382.7 & 321.8 & 0.84 & -1 & 12 & -1200 & 99.93 & 1 & 0.542 & 0.014 & 0.0704 & 0.0015 & 0.62639 & 0.05584 & 0.00079 & 446.0 & 31.4 & 439.9 & 9.1 & 438.3 & 9 & 99.6 \\
\hline LS14-019L-8Core-1 & 120.9 & 378.5 & 369.0 & 0.97 & 3 & 13 & 433 & 99.87 & 1 & 0.543 & 0.014 & 0.0705 & 0.0015 & 0.62198 & 0.05611 & 0.00089 & 456.7 & 35.2 & 440.6 & 9.4 & 439.0 & 9.1 & 99.6 \\
\hline LS14-019L-33Core-1 & 111.0 & 258.3 & 236.8 & 0.92 & -5 & 11 & -220 & 99.88 & 1 & .541 & 0.016 & 0.0702 & 0.0015 & 0.48104 & 0.05530 & 0.00110 & 424.4 & 44.4 & 438.8 & 11.0 & 437.4 & 9.2 & 99.7 \\
\hline LS14-019L-4Core-1 & 69.8 & 213.6 & 158.0 & 0.74 & 5 & 14 & 280 & 99.83 & 1 & 0.541 & 0.015 & 0.0704 & 0.0015 & 0.04801 & 0.05580 & 0.00100 & 444.4 & 39.8 & 439.9 & 9.9 & 438.8 & 8.8 & 99.7 \\
\hline LS14-019L-38Core-1 & 106.9 & 328.0 & 274.0 & 0.84 & 1 & 11 & 1100 & 99.93 & 1 & 0.550 & 0.014 & 0.0712 & 0.0015 & 0.46989 & 0.05525 & 0.00084 & 422.4 & 33.9 & 444.2 & 9.2 & 443.1 & 9.2 & 99.8 \\
\hline LS14-019L-6 & 56.1 & 182.3 & 191.0 & 1.05 & -2 & 22 & -1100 & 99.87 & 1 & 0.539 & 0.015 & 0.0700 & 0.0015 & 0.21552 & 0.05620 & 0.00120 & 460.3 & 47.3 & 437.0 & 10.0 & 436.3 & 8.8 & 99.8 \\
\hline \multicolumn{24}{|c|}{ CW15-014A Grand Falaise alkali feldspar granite (UTM: 656484E, 5171182N; NAD83, Grid Zone 20T) } \\
\hline CEW15-014A-61 & 104.1 & 346.3 & 189.0 & 0.55 & 3 & 13 & 433 & 99.67 & 1 & 0.519 & 0.013 & 0.0674 & 0.0019 & 0.17986 & 0.05570 & 0.00140 & 426.0 & 55.0 & 424.0 & 8.4 & 420.5 & 11 & 99.2 \\
\hline CEW15-014A-18 & 38.6 & 120.8 & 120.5 & 1.00 & -3 & 13 & 433 & 99.74 & 1 & 0.524 & 0.019 & 0.0684 & 0.0020 & 0.00878 & 0.05590 & 0.00210 & 439.0 & 79.0 & 430.0 & 13.0 & 426.5 & 12 & 99.2 \\
\hline CEW15-014A-56 & 129.2 & 411.3 & 277.5 & 0.67 & -5 & 12 & 240 & 99.68 & 1 & 0.527 & 0.010 & 0.0684 & 0.0019 & 0.11704 & 0.05590 & 0.00110 & 437.0 & 46.0 & 429.6 & 6.9 & 426.2 & 11 & 99.2 \\
\hline CEW15-014A-21 & 112.0 & 356.6 & 235.9 & 0.66 & 10 & 12 & 120 & 99.70 & 1 & 0.536 & 0.011 & 0.0695 & 0.0019 & 0.19261 & 0.05650 & 0.00110 & 464.0 & 45.0 & 436.2 & 7.2 & 432.8 & 11 & 99.2 \\
\hline CEW15-014A-1 & 109.4 & 353.0 & 237.9 & 0.67 & -9 & 13 & 144 & 99.59 & 1 & 0.523 & 0.012 & 0.0679 & 0.0019 & 0.14966 & 0.05670 & 0.00130 & 468.0 & 50.0 & 426.2 & 7.9 & 423.5 & 11 & 99.4 \\
\hline CEW15-014A-29 & 120.1 & 385.0 & 258.3 & 0.67 & 1 & 13 & 1300 & 99.67 & 1 & 0.526 & 0.012 & 0.0684 & 0.0019 & 0.16324 & 0.05550 & 0.00130 & 423.0 & 53.0 & 428.7 & 8.3 & 426.3 & 11 & 99.4 \\
\hline CEW15-014A-17 & 159.1 & 510.1 & 362.4 & 0.71 & -9 & 13 & 144 & 99.77 & 1 & 0.529 & 0.009 & 0.0688 & 0.0019 & 0.06733 & 0.05623 & 0.00099 & 457.0 & 40.0 & 430.8 & 6.0 & 428.8 & 11 & 99.5 \\
\hline CEW15-014A-60 & 208.3 & 666.0 & 412.0 & 0.62 & -9 & 12 & 133 & 99.77 & 1 & 0.528 & 0.009 & 0.0687 & 0.0019 & 0.31002 & 0.05577 & 0.00100 & 437.0 & 42.0 & 429.9 & 6.2 & 428.4 & 11 & 99.7 \\
\hline CEW15-014A-41 & 133.3 & 429.8 & 288.5 & 0.67 & -5 & 12 & 240 & 99.69 & 1 & 0.523 & 0.012 & 0.0682 & 0.0019 & 0.10943 & 0.05550 & 0.00140 & 414.0 & 53.0 & 426.6 & 8.2 & 425.5 & 11 & 99.7 \\
\hline CEW15-014A-33 & 47.4 & 154.0 & 94.0 & 0.61 & -11 & 13 & 118 & 99.68 & 1 & 0.519 & 0.016 & 0.0677 & 0.0020 & 0.17535 & 0.05640 & 0.00180 & 437.0 & 71.0 & 423.0 & 11.0 & 422.2 & 12 & 99.8 \\
\hline CEW15-014A-11 & 114.5 & 378.0 & 233.3 & 0.62 & 14 & 12 & 86 & 99.66 & 1 & 0.514 & 0.012 & 0.0674 & 0.0019 & 0.15515 & 0.05620 & 0.00130 & 459.0 & 51.0 & 421.1 & 7.9 & 420.4 & 11 & 99.8 \\
\hline \multicolumn{24}{|c|}{ CW14-121 French Mountain syenogranite (UTM: 659307E, 5178443N; NAD83, Grid Zone 20T) } \\
\hline CW14-121L-6_204 & $2265^{\circ}$ & 7100 & 611 & 0.09 & 3330 & 200 & 6 & 92.87 & 3 & 0.426 & 0.020 & 0.0564 & 0.0013 & 0.42647 & 0.10990 & 0.01200 & 1798 & 199 & 360.0 & 14.0 & 353.6 & 8.1 & 98.2 \\
\hline CW14-121L-7_204 & 2361 & 7665 & 1188 & 0.15 & 4340 & 170 & 4 & 92.29 & 3 & 0.448 & 0.028 & 0.0591 & 0.0014 & 0.32643 & 0.11580 & 0.00870 & 1892 & 135 & 375.2 & 20.0 & 370.1 & 8.6 & 98.6 \\
\hline CW14-121L-10_204 & 3403 & 11362 & 2577 & 0.23 & 1610 & 110 & 7 & 97.44 & 3 & 0.438 & 0.012 & 0.0584 & 0.0011 & 0.27152 & 0.07367 & 0.00091 & 1032 & 25 & 368.5 & 8.2 & 366.1 & 6.6 & 99.3 \\
\hline CW14-121L-11_204 & 2784 & 9270 & 2019 & 0.22 & 1910 & 160 & 8 & 97.00 & 3 & 0.438 & 0.010 & 0.0590 & 0.0010 & 0.18683 & 0.07750 & 0.00110 & 1134 & 28 & 368.5 & 7.1 & 369.7 & 6.1 & 100.3 \\
\hline CW14-121L-2_204 & 2857 & 7590 & 2870 & 0.38 & 7900 & 510 & 6 & 85.30 & 3 & 0.432 & 0.057 & 0.0588 & 0.0021 & 0.59059 & 0.17200 & 0.01100 & 2577 & 107 & 365.0 & 33.0 & 368.1 & \#\#\# & 100.8 \\
\hline
\end{tabular}

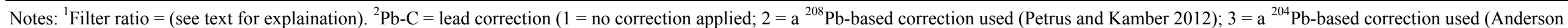
2002). ${ }^{207} \mathrm{~Pb} /{ }^{206} \mathrm{~Pb}$ isotopic ratios are uncorrected. 
Table 2. Sm-Nd isotopic data for samples from plutons in the Chéticamp belt.

$\begin{array}{ccccccccr}\text { Sample } & \text { Unit } & \begin{array}{c}\text { Age } \\ \mathbf{( M a )}\end{array} & \begin{array}{c}\mathbf{N d} \\ \mathbf{( p p m )}\end{array} & \begin{array}{c}\mathbf{S m} \\ \mathbf{( \mathbf { p p m } )}\end{array} & { }^{\mathbf{1 4 7}} \mathbf{S m} /{ }^{\mathbf{1 4 4}} \mathbf{N d} & { }^{\mathbf{1 4 3}} \mathbf{N d} /{ }^{\mathbf{1 4 4}} \mathbf{N d} & \begin{array}{c}\text { Epsilon } \\ \mathbf{N d}\end{array} & \begin{array}{c}\mathbf{T}_{\mathbf{D M}} \\ (\mathbf{G a})\end{array} \\ \text { LS-14-011 } & \text { FB } & 567 & 12.72 & 2.03 & 0.0962 & 0.512215 & -0.97 & 1.08 \\ \text { LS-14-071 } & \text { FB } & 567 & 24.29 & 4.16 & 0.1036 & 0.512287 & -0.10 & 1.05 \\ \text { LS-14-077 } & \text { CB } & 485 & 7.41 & 1.61 & 0.1310 & 0.512579 & 2.92 & 0.86 \\ \text { LS-14-081 } & \text { RB } & 567 & 22.14 & 3.82 & 0.1044 & 0.512265 & -0.59 & 1.09 \\ \text { K10-1084 } & \text { LB } & 440 & 35.84 & 7.40 & 0.1249 & 0.512577 & 2.85 & 0.81 \\ \text { K10-1086 } & \text { MB } & 440 & 26.84 & 5.07 & 0.1143 & 0.512500 & 1.95 & 0.84 \\ \text { K10-1101 } & \text { UFB } & 480 & 10.34 & 2.73 & 0.1593 & 0.512512 & -0.17 & 1.48 \\ \text { K10-1082 } & \text { PL } & 567 & 2.71 & 17.15 & 0.0957 & 0.512226 & -0.72 & 1.05\end{array}$

Abbreviations: Abbreviations: CB, Canadian Brook tonalite; FB, Farm Brook granodiorite; LB, Lavis Brook quartz diorite; MB = MacLean Brook granodiorite; RB, Rigwash Brook granodiorite; UFB, Upper Fisset Brook quartz diorite.

Notes: Chemical dissolution and isotope analyses were completed at McMaster University, Hamilton, ON. Sample powders were dissolved in $\mathrm{HF}$ and $\mathrm{HNO}_{3}$ at $125^{\circ} \mathrm{C}$ over a four-day period. The samples were then converted to the chloride form before splitting and spiking with a mixed ${ }^{150} \mathrm{Nd}-{ }^{149} \mathrm{Sm}$ solution. This was followed by standard cation and reverse phase column separation methods. Nd isotope analyses were done by dynamic multicollection using a VG isomass 354 mass spectrometer, and normalized to a ${ }^{146} \mathrm{Nd} /{ }^{144} \mathrm{Nd}$ ratio of 0.7219 . Average within-run precision on the samples was \pm 0.000013 ( 2 sigma), and an average value of $0.51185 \pm 2$ ( 2 sigma population) was determined for the La Jolla standard during this work. The reproducibility of ${ }^{147} \mathrm{Sm} /{ }^{144} \mathrm{Nd}$ and ${ }^{143} \mathrm{Nd} /{ }^{144} \mathrm{Nd}$ is estimated at $0.1 \%$ and $0.002 \%$ (1 sigma), respectively, leading to an analytical uncertainty on each model age of ca. $20 \mathrm{Ma}$ ( 2 sigma). Model age $\left(\mathrm{T}_{\mathrm{DM}}\right)$ was calculated using the model of DePaolo (1981). 